\title{
A convenient approach to an advanced intermediate toward the naturally occurring, bioactive 6-substituted 5-hydroxy- 4-aryl-1H-quinolin-2-ones $\dagger$
}

\author{
Sebastián O. Simonetti, Enrique L. Larghi* and Teodoro S. Kaufman* \\ 5-Hydroxy-4-aryl-3,4-dihydro-1H-quinolin-2-ones are a small family of natural products isolated from \\ fungal strains of Penicillium and Aspergillus. Most of its members, which are insecticides and anthelmin- \\ tics, carry an isoprenoid C- 6 side chain. The synthesis of a 6 -propenyl-substituted advanced intermediate \\ for the total synthesis of these natural products is presented in this paper. This was achieved through the \\ stereoselective construction of a $\beta, \beta$-diarylacrylate derivative from 6-nitrosalicylaldehyde, using a Wittig \\ olefination and a Heck-Matsuda arylation, followed by a selective $\mathrm{Fe}^{0}$-mediated reductive cyclization. \\ Installation of the 6 -propenyl side chain was performed by 5 -O-allylation of the heterocycle, followed by \\ Claisen rearrangement and conjugative migration of the allyl double bond, as the key steps. The Grubbs \\ II-catalyzed olefin cross metathesis of the 6-allyl moiety with 2-methylbut-2-ene to afford a precursor of \\ peniprequinolone is also reported.
}

Received 30th December 2015 Accepted 26th January 2016

DOI: $10.1039 / c 5 o b 02680 f$

www.rsc.org/obc
This research also afforded the yaequinolones A1 and A2 $(\mathbf{2 a}, \mathbf{b})$ and the quinolinones $\mathrm{A}$ and $\mathrm{B}(\mathbf{2 c}, \mathbf{d}){ }^{3 c, d, 4 a}$ Heterocycles $2 \mathbf{a}$ and $\mathbf{2 b}$ have been previously obtained from a $P$. janczewskii strain of marine origin, ${ }^{3 b, 4 b, c}$ whereas $2 \mathbf{c}$ and $2 \mathbf{d}$ were originally obtained from $P$. simplicissimum and found to behave as insecticidal antibiotics, ${ }^{3 c}$ being toxic against various cancer cell lines. ${ }^{3 b}$

In addition, two strains of Aspergillus were the source of the aflaquinolones A-D (4a-d) and the aflaquinolones E-G, which lack the $4^{\prime}$-OMe group. ${ }^{5 a}$ Some aflaquinolones have also been obtained from the endophyte A. nidulans MA-143, together with $\mathbf{1 h}$ and the aniduquinolones $\mathrm{A}-\mathrm{C}$. The latter, analogous to yaequinolones $\mathrm{C}$ and $\mathrm{F}$ (1) and $\mathbf{1 e}),{ }^{5 b}$ are lacking the $4^{\prime}$-OMe group.

More recently, the unusual 22-O-( $N$-methyl-L-valynyl) ester of aflaquinolone B (4e) and its epimer $\mathbf{4 f}$ were isolated from the mycelia of Aspergillus sp. XS-20090B15, together with the aflaquinolones $\mathrm{A}$ and $\mathrm{D}$ (or a diastereomer of it). ${ }^{5 c}$ Compound 4f exhibited remarkable anti-respiratory syncytial virus activity.

Genomic and biosynthetic studies suggested that this family may derive from anthranilic acid and phenylalanine or tyrosine, through the intermediacy of diketobenzodiazepines, ${ }^{2 a, 3 d}$ such as $\mathbf{3 a}, \mathbf{b}$, which have been isolated concomitantly. ${ }^{4 c}$ The latter undergo ring opening and re-cyclization to afford the basic 3,4-dihydro- $1 \mathrm{H}$-quinolin-2-one core, through the 4-phenylquinoline viridicatin as an intermediate. ${ }^{5 d-g}$ Next, $O$-methylation of the $-\mathrm{OH}$ moieties, installation of the C-4 and C-5 $-\mathrm{OH}$ groups, attachment of the C-6 side chains and further
Instituto de Química Rosario (IQUIR, CONICET-UNR) and Facultad de Ciencias Bioquímicas y Farmacéuticas, Universidad Nacional de Rosario, Suipacha 531, S2002LRK Rosario, Argentina. E-mail: kaufman@iquir-conicet.gov.ar; Fax: +54-341-4370477; Tel: +54-341-4370477

$\dagger$ Electronic supplementary information (ESI) available: Selected spectra of intermediates and the final product. See DOI: 10.1039/c5ob02680f 


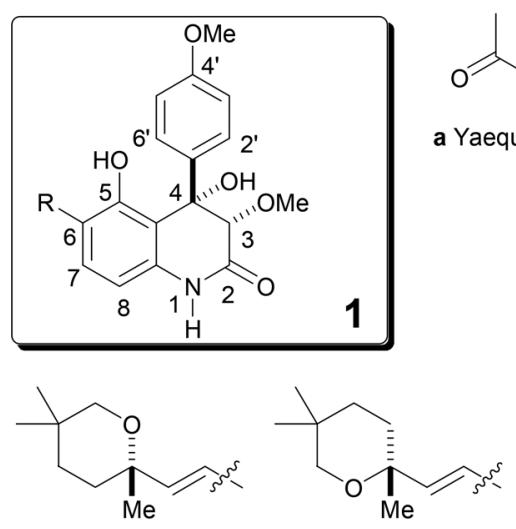

i Penigequinolone A j Penigequinolone B<smiles>[R]c1cccc2c1[C@@](O)(c1ccc(OC)cc1)C([R1])([R])C(=O)N2</smiles>

2a $R=R^{1}=H, R^{2}=O H$, ent-Yaequinolone $A_{1}$ 2b $R=R^{2}=H, R^{1}=O H$, Yaequinolone $A_{2}$ 2c $R=R^{2}=H, R^{1}=$ OMe, Quinolinone $A$ 2d $R=O H, R^{1}=H, R^{2}=O M e$, Quinolinone $B$
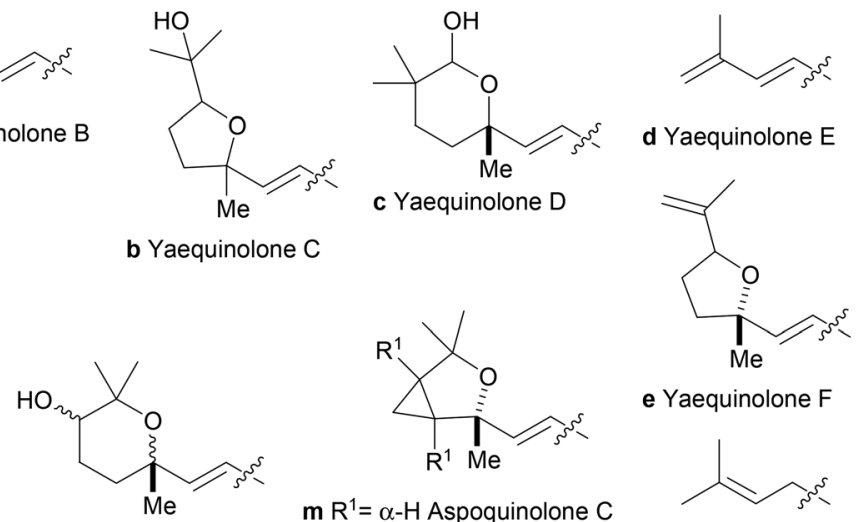

$m R^{1}=\alpha-H$ Aspoquinolone $C$

k,I Aspoquinolones A y B

n $\mathrm{R}^{1}=\beta-\mathrm{H}$ Aspoquinolone $\mathrm{D}$ e Yaequinolone $\mathrm{F}$<smiles>CC(C)=CCC(C)C</smiles>

h Peniprequinolone

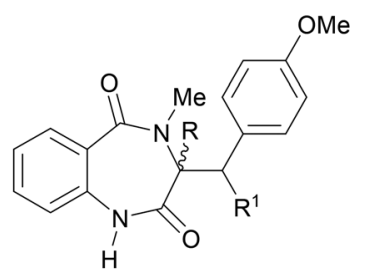

3a $R=R^{1}=H, 4^{\prime}$-methoxycyclopeptin 3b $R, R^{1}=$ double bond, trans-dehydro4'-methoxycyclopeptin<smiles>COc1ccc([C@]2(O)c3c(ccc4c3O[C@](C)(CCC=C(C)C)C=C4)NC(=O)[C@@H]2OC)cc1</smiles>

f Yaequinolone J1 (S) g Yaequinolone J2 $(R)$

Fig. 1 Chemical structures of representative naturally-occurring 6-substituted 5-hydroxy-4-aryl-1H-quinolin-2-ones and their congeners. Except for $2 \mathrm{a}$ and $\mathbf{2 d}$, it is assumed that the heterocycles bear a cis-3,4-dioxygenated pattern and exhibit the same $35,4 S$ configuration.

functionalization would explain their diversity. ${ }^{5 h}$ The natural products are optically active, displaying a $3 S, 4 S$ configuration. ${ }^{3 b, 5 a}$

Ectoparasiticidal and antiproliferative preparations containing some of these heterocycles have been patented. ${ }^{6 a-e}$ However, synthetic activity in this area has been very scarce. ${ }^{6 f, g}$

In pursuit of a common general synthetic approach to the members of this family of natural products, herein we report a concise route to a potential common key intermediate for the 6-substituted 5-hydroxy-4-aryl-3,4-dihydro-1 $\mathrm{H}$-quinolin-2-ones, bearing the fundamental structural motif 1 . In addition, the synthesis of a peniprequinolone (1/h) derivative, lacking the 3,4-glycol monomethyl ether feature, is disclosed.

\section{Results and discussion}

There are five main synthetic approaches to 4-alkyl/aryl-substituted $1 H$-quinolin-2-ones (Fig. 2), which relate to the single bond involved in closing the heterocyclic ring. ${ }^{7 a}$ These consist of types (a), ${ }^{7 b-g}$ (b), ${ }^{8 a}$ (c),$^{8 b}$ (d),${ }^{8 c, d}$ and (e). ${ }^{8 e_{f} f}$ However, strategies of types (b) and (c) are unsuitable for the synthesis of 5-hydroxy/alkoxy substituted heterocycles, mainly due to their narrow scope and difficulties to access the starting materials, whereas type (a) demands starting from 1,2,4-substituted benzenoids, ${ }^{9 a-g}$ to block the preferred alternative cyclization mode, en route to 7-hydroxy/alkoxy derivatives. ${ }^{9 h, i}$

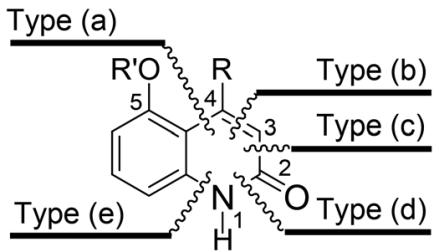

Fig. 2 Most relevant general strategies for the synthesis of 4-substituted $1 \mathrm{H}$-quinolin-2-ones.

Hence, our approach to the natural products $(5$, Scheme 1) relied on a retrosynthetic analysis involving strategies of types (d) and (e). The C-6 substituent of the target was disconnected at the double bond level, considering that the side chains could be installed by olefin cross-metathesis of a 6-vinyl quinolin-2-one. It was also inferred that the cis-3,4-diol monoether system could result from dihydroxylation of a $\Delta^{3,4}$ precursor, ${ }^{10}$ and selective alkylation of the less hindered alcohol, revealing 6 to be the suitable common advanced key intermediate sought.

Generally, $\beta$-substituted styrenes are less costly and easier to prepare than their styrene counterparts, and also more stable and less prone to undergo homodimerization or spontaneous polymerization. ${ }^{11 a-d}$ Therefore, it was considered installing a 6-propenyl side chain (6a), taking advantage of the 5 -OH group. ${ }^{11 e}$ 


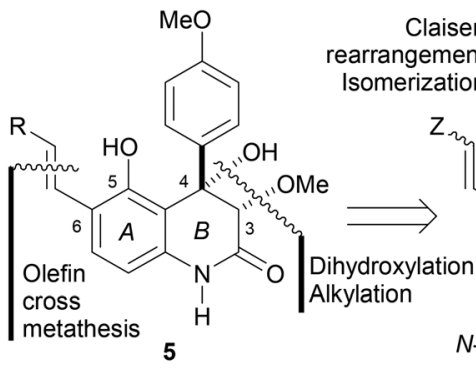

$\mathrm{R}=$ See Figu
$\mathrm{R}^{1}=\mathrm{OMe}, \mathrm{O}$
$\mathrm{R}^{2}=\mathrm{Bn}, \mathrm{PMB}$
$\mathrm{R}^{3}=\mathrm{Me}, \mathrm{Et}$
$\mathrm{X}=\mathrm{H}, \mathrm{Br}, \mathrm{NH}$

11

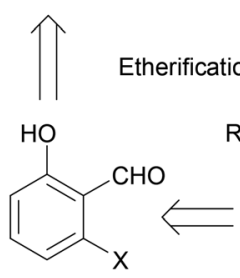

10

cheme 1 General retrosynthetic analysis of the natural products 5 . Target heterocycles 6 and 6 a as advanced key intermediates.

Conjecturing that the heterocyclic ring could be accessed by lactamization of a $\beta, \beta$-diarylacrylate with a suitably placed amine attached to the aromatic ring [type (d)], ${ }^{12 a, b}$ or by $N$-arylation [type (e)],,$^{8 e, 12 c, d}$ revealed 7 to be a potential precursor of 6a (route a). In turn, it was conceived that $\beta, \beta$-diarylacrylate 7 could be obtained from a cinnamic acid derivative (8). ${ }^{13 a, b}$

On the other hand, it was supposed that compound 9, which could also be made available from cinnamate $\mathbf{8}$, might also be considered a suitable precursor of $\mathbf{6 a}$ (route b); however, previous findings on the resistance of certain $1 \mathrm{H}$-quinolin-2-ones to undergo the Heck reaction on $\mathrm{C}-4^{12 c}$ discouraged exploration of this alternate route as the first choice. Further examination of $\mathbf{8}$ uncovered a precursor aldehyde moiety $^{14}$ and unveiled a phenol, suggesting aldehydes 10, obtainable from commercially available phenols $\mathbf{1 1}$, to be suitable starting materials.

The type (e) approach was explored first. Therefore, salicylaldehyde (12) was subjected to a Williamson etherification with benzyl chloride in absolute EtOH, employing $\mathrm{K}_{2} \mathrm{CO}_{3}$ as a base, which afforded 99\% of benzyl ether 13 (Scheme 2). In turn, the aldehyde 13 was exposed to a Hörner-WadsworthEmmons (HWE) reaction with $(\mathrm{MeO})_{2} \mathrm{P}(\mathrm{O}) \mathrm{CH}_{2} \mathrm{CO}_{2} \mathrm{Me}$, furnishing $55 \%$ of cinnamate $\mathbf{1 4}$. However, better results were obtained when 13 was subjected to a Wittig olefination with

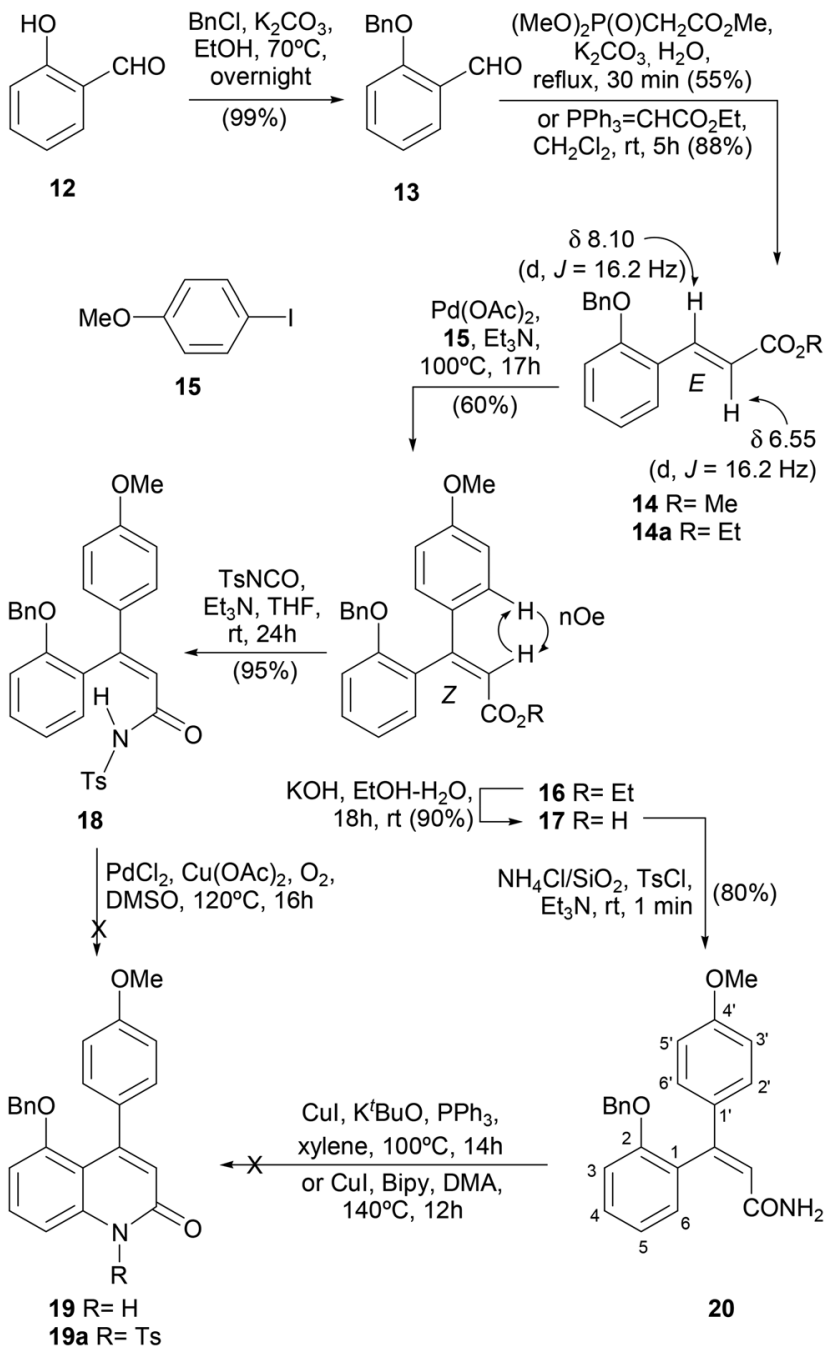

Scheme 2 Attempted synthesis of intermediates 19 from salicylaldehyde (12).

carbethoxymethylene triphenylphosphorane, which gave $88 \%$ of cinnamate 14a, as a $4: 1$ mixture of geometric $(E: Z)$ isomers, according to the ${ }^{1} \mathrm{H}$ NMR integration.

Installation of the 4-methoxyphenyl moiety was accomplished by means of a Heck reaction ${ }^{15}$ of $14 a$ with 4-iodoanisole (15) in refluxing $\mathrm{Et}_{3} \mathrm{~N}$, under $\mathrm{Pd}(\mathrm{OAc})_{2}$ catalysis, which provided the $\beta, \beta$-diphenylacrylate 16 as a $86: 14\left({ }^{1} \mathrm{H}\right.$ NMR integration) mixture of geometric isomers, in $60 \%$ combined yield. The $Z$-configuration of the main isomer of $\mathbf{1 6}$ was ascertained with the aid of nOe experiments, which revealed mutual signal enhancement between the vinylic proton next to the carboxylate ester and the aromatic protons located meta to the $4^{\prime}$ methoxy group (2'-H and 6'-H).

In order to insert the required nitrogen atom and properly activate the $\beta, \beta$-diphenylethylene derivative toward cyclization, the ester 16 was saponified (90\%) and the resulting carboxylic acid 17 was reacted with tosyl isocyanate in the presence of $\mathrm{Et}_{3} \mathrm{~N}$, furnishing the tosylimide derivative 18 (95\%). ${ }^{8 e, 16} \mathrm{Un}$ fortunately, however, all attempts to cyclize 18 under Pd catalysis, 
with $\mathrm{Cu}(\mathrm{OAc})_{2}$ as a co-catalyst and aerobic conditions, ${ }^{8 e}$ met with failure, resulting in complete degradation of the tosylimide.

It seems likely that the lability of $\mathbf{1 8}$ toward the cyclization conditions that would lead to 19 a may be related to its structure, because exposure of the $\beta, \beta$-diphenylacrylic acid tosylimide to the same cyclization conditions afforded $70 \%$ of the expected 4-phenyl- $1 H$-quinolin-2-one, completely agreeing with the literature.

In view of this outcome, the copper-catalyzed cyclization of amide 20 was explored as an alternative. Amidation of ester $\mathbf{1 6}$ with ammonia met with failure; ${ }^{17 a}$ therefore, the acid 17 was amidated with $\mathrm{NH}_{4} \mathrm{Cl} / \mathrm{TsCl}$ supported on a silica gel, under $\mathrm{Et}_{3} \mathrm{~N}$ promotion, affording $80 \%$ of $20 .{ }^{17 b}$ However, exposure of the amide to various copper-mediated $\mathrm{C}-\mathrm{H}$ activation proto$\operatorname{cols}^{8 f, 18}$ resulted in complete recovery of the starting amide $\mathbf{2 0 .}$

Therefore, the attention changed to a type (d) strategy, which involves forming the $\mathrm{Ar}-\mathrm{N}$ bond prior to cyclization or entails using starting materials which already contain the heteroatom. ${ }^{8 d, e}$

3-Nitrophenol (21) was selected as the new starting material, considering that the nitro moiety could mask the required amino group during the initial stages and that it could be engaged in a one-pot reductive cyclization $(7 \rightarrow 6),{ }^{19}$ under conditions that could also result in the removal of the protecting benzyl ether.

With these ideas in mind, compound 21 was subjected to a Duff formylation with hexamethylenetetramine (HMTA) in $\mathrm{F}_{3} \mathrm{CCO}_{2} \mathrm{H}$ at $110{ }^{\circ} \mathrm{C}$ for $12 \mathrm{~h}$, affording the expected aldehyde 22 as an 85:15 mixture with its isomer 22a, in 54\% combined yield. Notably, previous syntheses of 22 took place with rather lower yields. ${ }^{20}$ In turn, phenol 22 was subjected to a Williamson etherification with $\mathrm{BnCl}$ in refluxing $\mathrm{EtOH}$, employing $\mathrm{K}_{2} \mathrm{CO}_{3}$ as a base, to give 23 in almost quantitative yield (Scheme 3).

Introduction of the two-carbon moiety required for building the $1 H$-quinolin-2-one feature was performed by means of a Wittig reaction ${ }^{21}$ with ethyl(triphenyl- $\lambda 5$-phosphanylidene)acetate, affording $88 \%$ of cinnamate $24 .{ }^{22}$ The coupling constants of the vinylic hydrogens $(J=16.2 \mathrm{~Hz})$ unequivocally established the stereochemistry of $\mathbf{2 4}$ as $E$.

When the Heck conditions leading to $\mathbf{1 6}$ were applied to $\mathbf{2 4}$, the corresponding $\beta, \beta$-diarylacrylate was obtained in $55 \%$ yield, confirming previous observations where the reaction was found to lose efficiency when attempting to introduce electron-rich aryl groups. ${ }^{23}$ This suggested the need for an alternate strategy.

Although alternative Heck protocols were available, ${ }^{24 a}$ the Heck-Matsuda reaction seemed a suitable transformation to fulfil our expectations, since it is apparently devoid of this drawback. ${ }^{24 b-e}$ Recent examples from the laboratory of Correia were encouraging; furthermore, the $p$-anisidine reagent required for introducing the 4-methoxyphenyl moiety is readily available, and is several times less expensive than $p$-iodoanisol.

Thus, exposure of a refluxing methanolic mixture of cinnamate $\mathbf{2 4}$ and the diazonium tetrafluoroborate $\mathbf{2 5}$, derived from

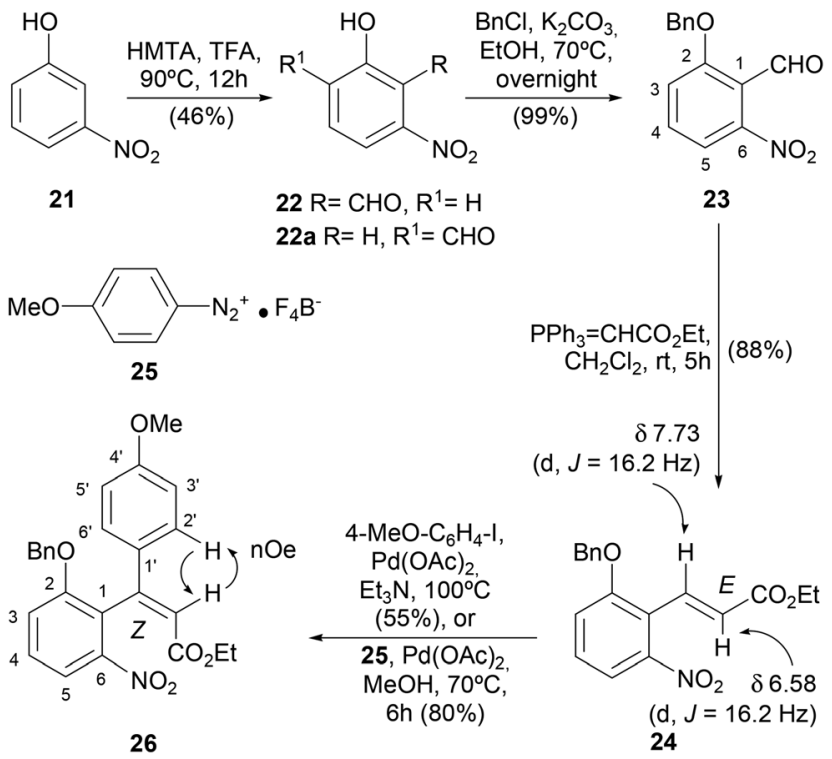

Scheme 3 Synthesis of the intermediate 26 from 3-nitrophenol (21).

$p$-anisidine ${ }^{24 d}$ to $\mathrm{Pd}(\mathrm{OAc})_{2}$ catalysis, furnished $80 \%$ of the $\beta, \beta$-diarylacrylate 26 .

An nOe experiment, revealing mutual signal enhancement between the vinylic proton of the acrylate motif $(\delta 6.45$, singlet) and the neighbouring aromatic protons of the 4-methoxyaryl moiety ( $\delta 7.33, \mathrm{~d}, J=8.8 \mathrm{~Hz}$ ), established the $Z$ geometry of 26 . This outcome of the Heck-Matsuda reaction, analogous to that of the Heck arylation, ${ }^{25}$ has been explained mechanistically. ${ }^{26}$

Next, the one pot benzyl ether group hydrogenolysis with a concomitant reduction of the nitro moiety to the corresponding amino-derivative $\mathbf{2 9}$ and further cyclization toward 27 was attempted on 26. However, when the Pd-mediated catalytic hydrogenation was attempted under a variety of conditions, ${ }^{27}$ it exhibited several unforeseen problems, which ranged from partial reduction of the nitro group to concomitant hydrogenation of the acrylate double bond, despite being sterically hindered.

Thus, the hydrogenation with $10 \% \mathrm{Pd} / \mathrm{C}$ in $\mathrm{MeOH}$ at room temperature produced equal amounts of 19 and its debenzylated analog 27 in 30\% combined yield (Table 1, entry 1), whereas the reaction proceeded more sluggishly in EtOH (entry 2).

However, addition of $\mathrm{Et}_{3} \mathrm{~N}$ to the ethanolic medium provoked the hydrogenation of the nitro moiety and the subsequent cyclization, but also the debenzylation and hydrogenation of the $\Delta^{3,4}$ double bond, furnishing $61 \%$ of 28 (entry 3). On the other hand, when the reaction was run in refluxing toluene, a 30:70 mixture of cyclized (19) and debenzylated and uncyclized products (29) was obtained in $25 \%$ combined yield (entry 4).

Considering the above results, a stepwise strategy was devised, prioritizing the sequential nitro group reductioncyclization toward 19. Unfortunately, $\mathrm{SnCl}_{2}$ in $\mathrm{EtOH}^{28}$ also gave $40 \%$ of a $37: 63$ mixture of 19 and 29 when the reaction was 


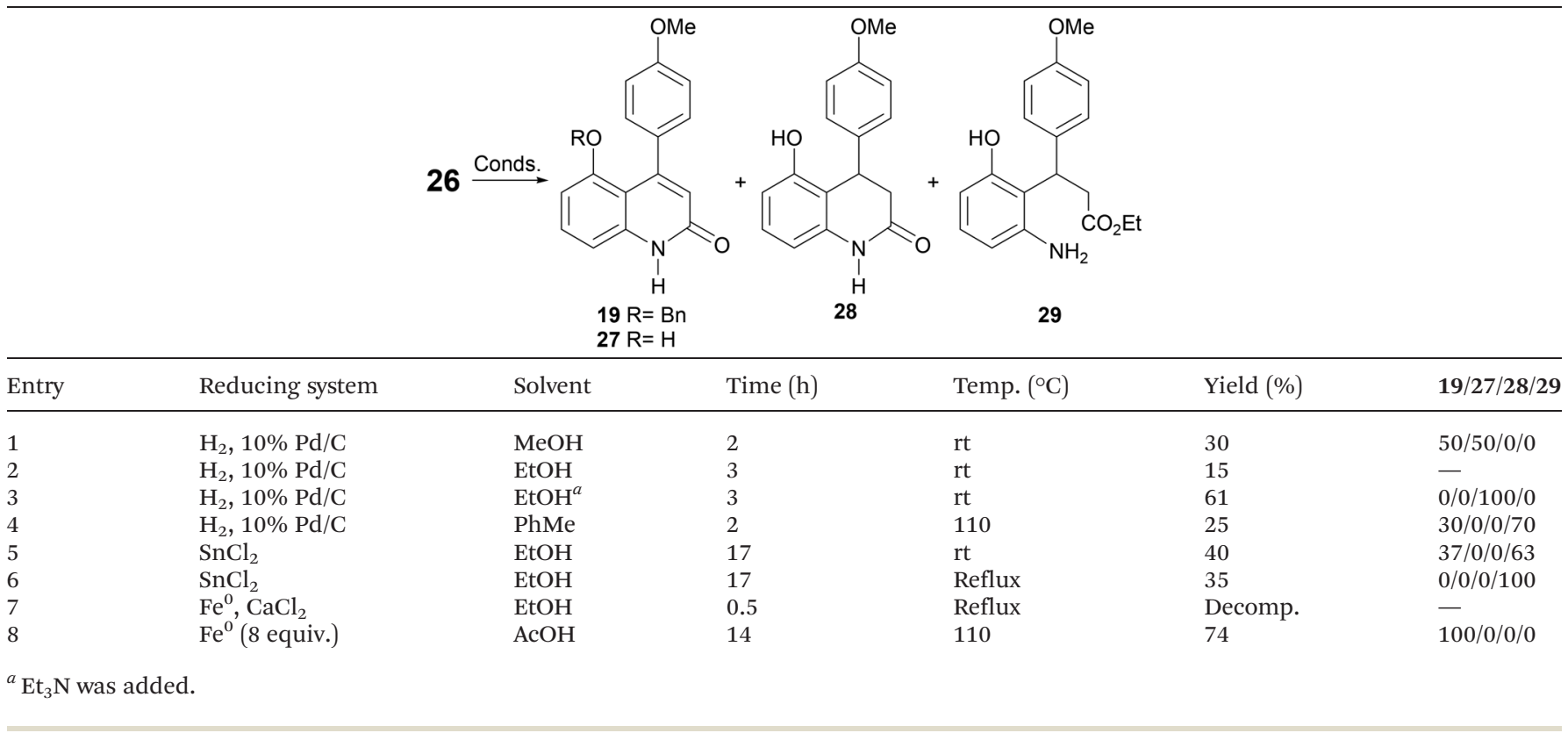

performed at room temperature (entry 5), and only 29 was isolated $(35 \%)$ when the transformation was carried out under reflux (entry 6). The formation of $\mathbf{2 9}$ under these different conditions ruled out employing $\mathrm{SnCl}_{2}$ as the reducing agent for this step.

On the other hand, the use of the $\mathrm{Fe} / \mathrm{CaCl}_{2}$ system in refluxing $\mathrm{EtOH}^{29 a}$ unexpectedly furnished solely degradation products (entry 7). However, to our delight, exposure of 26 to elemental iron powder in glacial $\mathrm{AcOH}$ at $110{ }^{\circ} \mathrm{C}$ resulted in the selective reduction of the nitro moiety to $\mathbf{3 0}$ and subsequent lactamization, cleanly affording $74 \%$ of $\mathbf{1 9}$ as the sole product (entry 8). ${ }^{29 b-d}$

With the core $1 H$-quinolin-2-one 19 in hands (Scheme 4), the next steps were devoted to the installation of the C-6 $\beta$-propenyl side chain. Therefore, proper conditions were sought for the selective debenzylation of $\mathbf{1 9}$ and $O$-allylation of $27 .{ }^{30 a}$

The results of Table 1 seemed to confirm the literature observations that characterized the selective debenzylation of aryl benzyl ethers in the presence of $\mathrm{C}-\mathrm{C}$ double bonds as 'difficult'. ${ }^{30 b}$ However, in the case of $\mathbf{1 9}$, after several trial and error attempts under different conditions, it was learned that $10 \% \mathrm{Pd} / \mathrm{C}$ in a cold 1:1 (v/v) EtOH-EtOAc solvent mixture under an atmospheric pressure of hydrogen was an effective system for selectively cleaving the benzyl ether without affecting the $\Delta^{3,4}$ double bond. ${ }^{30 c}$ Under these conditions, $89 \%$ of 27 was reliably obtained after $4 \mathrm{~h}$.

Next, the selective $O$-allylation of the phenol moiety of 27 was undertaken. Literature precedents suggested that the ambident anion at $\mathrm{N}-1-\mathrm{C}-2$ is a potentially competitive reaction site ${ }^{30 a, 31}$ and that, in principle, the $O$-allylation should predominate. ${ }^{30 a}$

In fact, when compound 27 was subjected to a conventional Williamson allylation, with $\mathrm{K}_{2} \mathrm{CO}_{3}$ in $\mathrm{EtOH}$ at $60^{\circ} \mathrm{C}, 65 \%$ of the expected $O$-allyl derivative $\mathbf{3 1}$ was obtained and, to our

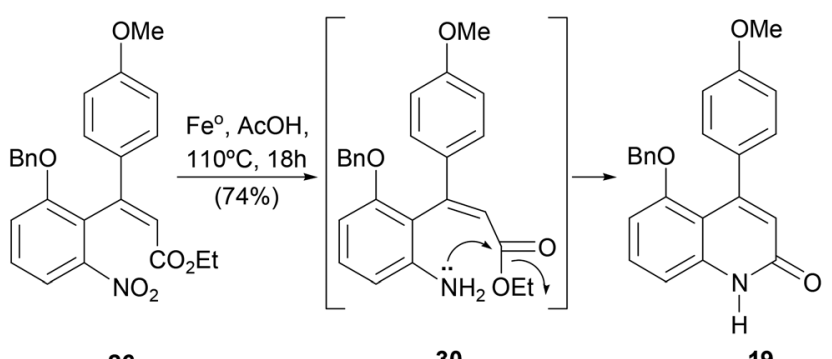

26

30

19

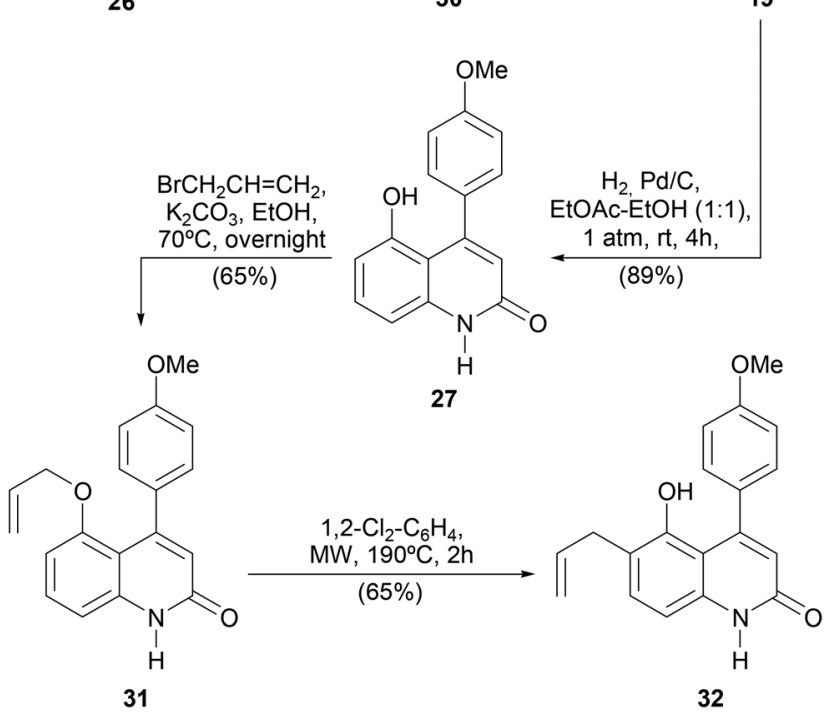

Scheme 4 Construction of the 2-quinolonic ring and synthesis of 32.

delight, no other alkylation products were observed. Submission of ether $\mathbf{3 1}$ to the projected Claisen rearrangement took place under microwave irradiation in 1,2-dichlorobenzene, affording $75 \%$ of the desired 6-allyl derivative $\mathbf{3 2}$. 
Interestingly, the 6-allyl $1 H$-quinolin-2-ones have elicited great synthetic and pharmaceutical interest, having also been used as intermediates toward drugs for treating cardiac diseases, protecting against UV rays, scavenging active oxygen species, and inhibiting enzymes as well as lipid peroxidation. $^{32}$

The acquisition of compound 32 enabled the proposed synthesis of 33, a peniprequinolone (1h) analog lacking its 3,4glycol monoether feature (Scheme 5). This target was conveniently achieved in $77 \%$ yield by olefin cross metathesis of 32 with 2-methylbut-2-ene, under Grubbs II catalyst promotion in refluxing $\mathrm{CH}_{2} \mathrm{Cl}_{2} \cdot{ }^{33}$

However, the achievement of the second and main objective proved more difficult. Unexpectedly, the isomerization of the terminal double bond of $\mathbf{3 2}$ toward $\mathbf{3 4}$ proved to be challenging under a wide range of catalysts and conditions.

The attempts employing stressed Grubbs-II catalyst $(\mathrm{MeOH}$, $\left.60{ }^{\circ} \mathrm{C}, 3 \mathrm{~h}\right), \mathrm{RhCl}_{3} \cdot 3 \mathrm{H}_{2} \mathrm{O}(\mathrm{EtOH}, \mathrm{rt}, 7 \mathrm{~h}), \mathrm{Pd}\left(\mathrm{PPh}_{3}\right)_{2} \mathrm{Cl}_{2}\left(\mathrm{CHCl}_{3}\right.$, $\left.40{ }^{\circ} \mathrm{C}, 4 \mathrm{~h}\right)$ and $\left[\left(\mathrm{C}_{6} \mathrm{H}_{5}\right)_{3} \mathrm{P}\right]_{3} \mathrm{Ru}(\mathrm{CO})(\mathrm{Cl}) \mathrm{H}\left(\mathrm{PhMe}, 90{ }^{\circ} \mathrm{C}, 18 \mathrm{~h}\right)$ met with failure, and an unexpected complete degradation of the starting material with a concomitant production of complex mixtures of unidentifiable products was invariably observed. This was somewhat reminiscent of the outcome of a similar attempt at allyl group isomerization during the synthesis of an intermediate for fumimycin. ${ }^{34}$

We speculated that under the isomerization conditions, either the free phenol or the amide of $\mathbf{3 4}$ (or even its less contributing phenolic lactim moiety) could lead to structural destabilization of the product, by acid-base or metal-promoted tautomerization to quinone methides, which in turn could undergo degradation.

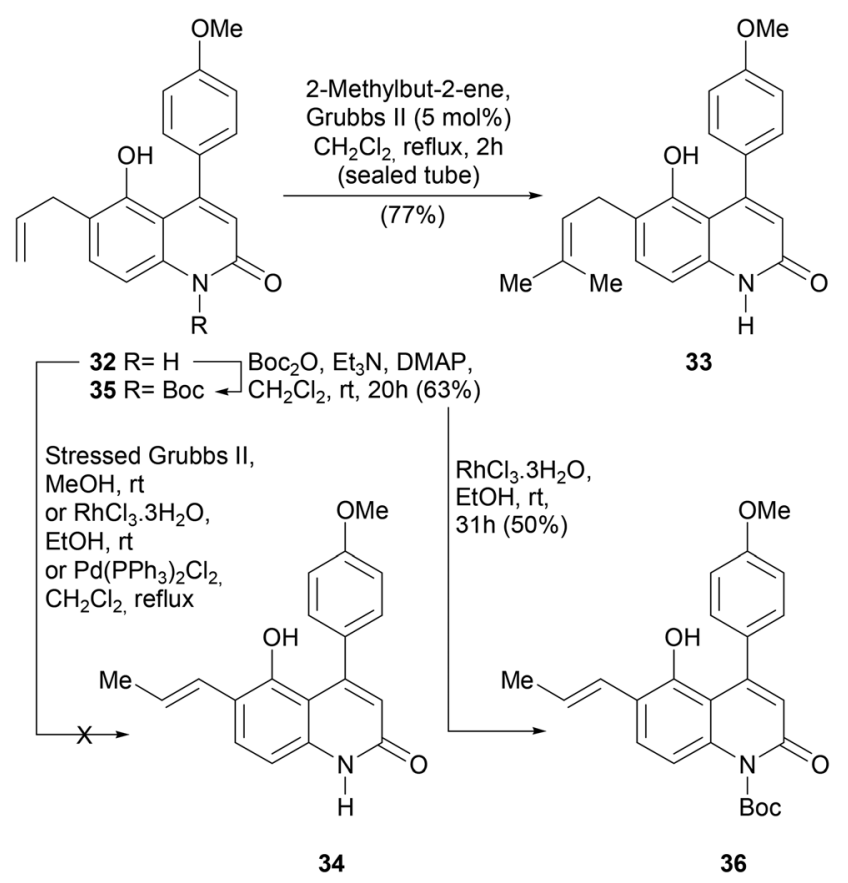

Scheme 5 Syntheses of the target compounds 33 and 36 .
It has been proposed that quinone methides are formed as intermediates during Pd-catalyzed reactions of 2-vinyl phenols and other conditions involving easily protonable or otherwise reactive benzylic positions and properly placed phenolic groups. ${ }^{35}$ These are highly reactive species, capable of undergoing different reactions, including polymerization. Further after observing that $\mathbf{3 4}$ was fully recovered after exposure to $\mathrm{K}^{t} \mathrm{BuO}$ in THF for $12 \mathrm{~h}$ at room temperature, it was conceived that perhaps the organometallic intermediates and not the isomerized product $\mathbf{3 4}$ may be the ones that trigger the degradation of the heterocycle.

In light of this situation, it was decided to block the possible involvement of the lactam moiety of 32 in the tautomerization reaction, through its protection as the $\mathrm{N}$-Boc derivative 35. ${ }^{36}$ This was accomplished in $63 \%$ yield with $\mathrm{Boc}_{2} \mathrm{O}$ and $\mathrm{Et}_{3} \mathrm{~N}$ in $\mathrm{CH}_{2} \mathrm{Cl}_{2}$. Surprisingly, however, the isomerization remained challenging, as compound 35 was also reluctant to cleanly afford the isomerized product. Its exposure to $\left[\left(\mathrm{C}_{6} \mathrm{H}_{5}\right)_{3} \mathrm{P}\right]_{3} \mathrm{Ru}(\mathrm{CO})(\mathrm{Cl}) \mathrm{H}$ in toluene for $17 \mathrm{~h}$ at $70{ }^{\circ} \mathrm{C}$ did not afford any isomerized product, whereas heating at $90{ }^{\circ} \mathrm{C}$ for $24 \mathrm{~h}$ furnished the expected heterocycle 36, albeit contaminated with $\mathrm{PPh}_{3} \mathrm{O}$, which turned difficult to remove chromatographically. On the other hand, the use of $\operatorname{Pd}\left(\mathrm{PPh}_{3}\right)_{2} \mathrm{Cl}_{2}$ $\left(\mathrm{CHCl}_{3}, \mathrm{rt}, 3 \mathrm{~h}\right)$ gave a mixture of unidentifiable products.

Finally, our expectations were met when exposure of 35 to $\mathrm{RhCl}_{3} \cdot 3 \mathrm{H}_{2} \mathrm{O}$ in absolute EtOH resulted in the smooth isomerization of the allyl moiety, furnishing $50 \%$ of the sought product 36, when the reaction was left for $31 \mathrm{~h}$ at room temperature. Analysis of its ${ }^{1} \mathrm{H}$ NMR spectrum, which exhibited signals at $\delta 6.19$ (dd, $J=6.3$ and $15.7 \mathrm{~Hz}, \mathrm{CH}_{3}-\mathrm{CH}=\mathrm{CH}-\mathrm{Ar}$ ) and $\delta 6.36\left(\mathrm{~d}, J=15.7 \mathrm{~Hz}, \mathrm{CH}_{3}-\mathrm{CH}=\mathrm{CH}-\mathrm{Ar}\right)$, unequivocally confirmed the $E$-stereochemistry of the $\beta$-methylstyrene unit in 36.

\section{Conclusions}

We have developed a convenient approach to an advanced common key intermediate for the synthesis of relevant members of the 6-substituted 5-hydroxy-4-aryl-3,4-dihydro- $1 \mathrm{H}^{-}$ quinolin-2-one family of natural products. The synthetic strategy entailed building and cyclization of a substituted $\beta, \beta$-diarylacrylate derivative to construct the heterocyclic core. The sequence was completed by an optimized selective catalytic debenzylation and installation of the anchoring $\beta$-propenyl moiety, by an $O$-allylation, followed by Claisen rearrangement and conjugative double bond migration of the resulting 6-allyl$1 H$-quinolin-2-one.

The synthesis took place in nine steps and proceeded in $6.1 \%$ overall yield, from the known 2-hydroxy-6-nitrobenzaldehyde, in turn available in one step from commercial 3-nitrophenol.

Further, an analog of peniprequinolone, lacking its 3,4glycol monomethyl ether feature, was also synthesized by means of a Grubbs II-catalyzed cross metathesis of the 6-allyl$1 H$-quinolin-2-one intermediate with 2-methylbut-2-ene. 
Studies are under way to establish the conditions for the installation of the characteristic C-3-C-4 monoprotected cisdiol feature. The results will be communicated in due time.

\section{Experimental section}

\section{General information}

All the reactions were carried out under dry nitrogen or argon atmospheres, employing oven-dried glassware. Anhydrous THF and anhydrous $\mathrm{CH}_{2} \mathrm{Cl}_{2}$ were obtained from an $\mathrm{M}$. Braun solvent purification and dispenser system. Absolute $\mathrm{MeOH}$ and $\mathrm{EtOH}$ were accessed by refluxing the solvents over clean $\mathrm{Mg} / \mathrm{I}_{2}$ and distilling from the resulting magnesium alkoxides; anhydrous 1,2-dichlorobenzene was prepared by a $4 \mathrm{~h}$ reflux of the solvent over $\mathrm{P}_{2} \mathrm{O}_{5}$ followed by atmospheric pressure distillation. All other reagents were used as received.

The flash column chromatographies were run with Merck's silica gel $60 \mathrm{H}$, eluting with hexane/EtOAc mixtures, under positive pressure and employing gradient of solvent polarity techniques.

All new compounds gave single spots on TLC plates (silica gel $60 \mathrm{GF}_{254}$ ) run in different hexane/EtOAc and EtOAc/EtOH solvent systems. The chromatographic spots were detected by exposure to $254 \mathrm{~nm}$ UV light, followed by spraying with ethanolic $p$-anisaldehyde/sulfuric acid reagent, $1 \%$ methanolic $\mathrm{FeCl}_{3}$, ninhydrin or Dragendorff reagent (Munier and Macheboeuf modification), ${ }^{37}$ and finally careful heating of the plates for improving selectivity.

\section{Apparatus}

The melting points were measured on an Ernst Leitz Wetzlar model 350 hot-stage microscope and are reported uncorrected. The IR spectra were recorded with a Shimadzu Prestige 21 spectrophotometer, as thin films held between NaCl cells, as solid dispersions in $\mathrm{KBr}$ disks, or with a Pike ATR accessory.

The ${ }^{1} \mathrm{H}$ NMR spectra were acquired at $300.13 \mathrm{MHz}$ in $\mathrm{CDCl}_{3}$, unless noted otherwise, on a Bruker Avance spectrometer. Chemical shifts are reported in parts per million on the $\delta$ scale and $J$-values are given in hertz. The peak of the residual protonated solvent $\left(\mathrm{CHCl}_{3}\right.$ in $\left.\mathrm{CDCl}_{3}, \delta 7.26\right)$ was used as the internal standard. The ${ }^{13} \mathrm{C}$ NMR spectra were recorded at $75.48 \mathrm{MHz}$ on a Bruker Avance spectrometer. The solvent peak $\left(\mathrm{CDCl}_{3}, \delta 77.0\right)$ was used as the internal standard. DEPT 135 and DEPT 90 experiments aided the interpretation and assignment of the fully decoupled ${ }^{13} \mathrm{C}$ NMR spectra. In special cases, 2D-NMR experiments (COSY, HMBC and HMQC) were also employed. Pairs of signals marked with an asterisk (*) indicate that their assignments may be exchanged.

The high resolution mass spectra were obtained with a Bruker MicroTOF-Q II instrument (Bruker Daltonics, Billerica, MA). Detection of the ions was performed in electrospray ionization, positive ion mode. The GC-MS experiments were carried out with a Shimadzu QP2010 plus instrument. The runs were performed in split injection mode (ratio: 50), column SPB-1 $(30 \mathrm{~m} \times 0.25 \mathrm{~mm} \times 0.25 \mu \mathrm{m})$; oven temperature program $T_{\text {Init. }}: 50{ }^{\circ} \mathrm{C}(3 \mathrm{~min}) ; T_{\text {End }}: 300{ }^{\circ} \mathrm{C}$, at $25{ }^{\circ} \mathrm{C} \mathrm{min}^{-1}$; He flow: $1.0 \mathrm{~mL} \mathrm{~min}^{-1}$. Mass spectra were obtained under the following conditions: $T_{\text {Interface }}: 300{ }^{\circ} \mathrm{C}$; $T_{\text {Ion source }}: 230{ }^{\circ} \mathrm{C}$; Solvent cut time: $3 \mathrm{~min}$; ionization $=70 \mathrm{eV}$; range: $60-600 \mathrm{Da}$. The microwave-assisted reactions were performed on a CEM Discover microwave oven.

2-Hydroxy-6-nitrobenzaldehyde (22). A solution of 3-nitrophenol $(21,1000 \mathrm{mg}, 7.20 \mathrm{mmol})$ in $\mathrm{F}_{3} \mathrm{CCO}_{2} \mathrm{H}(8 \mathrm{~mL})$ was treated with HMTA $(1200 \mathrm{mg}, 8.59 \mathrm{mmol})$ and the mixture was heated at $90{ }^{\circ} \mathrm{C}$ for $12 \mathrm{~h}$. The reaction was poured over icewater $(25 \mathrm{~mL})$, and the resultant mixture was stirred for $15 \mathrm{~min}$ and then extracted with EtOAc $(3 \times 40 \mathrm{~mL})$. The organic layers were washed with brine $(20 \mathrm{~mL})$, dried under $\mathrm{Na}_{2} \mathrm{SO}_{4}$ and concentrated in vacuo. Chromatography of the oily residue afforded 22 (560 mg, 46\%) as a yellow solid, m.p.: $52-54{ }^{\circ} \mathrm{C}$ (lit.: $\left.53-54{ }^{\circ} \mathrm{C}\right) .{ }^{20 a} \mathrm{IR}(\mathrm{KBr}, \nu)$ : 3300, 2955, 2922, 2851, 1693, 1645, 1531, 1454, 1352 and $1284 \mathrm{~cm}^{-1} .{ }^{1} \mathrm{H} \operatorname{NMR}(\delta): 7.30$ (d, $1 \mathrm{H}, J=8.0, \mathrm{H}-3), 7.56$ (d, 1H, $J=8.0, \mathrm{H}-5), 7.63$ (t, 1H, $J=$ 8.0, H-4), 10.33 (s, 1H, CHO) and $12.11(\mathrm{~s}, 1 \mathrm{H}, \mathrm{OH}) .{ }^{13} \mathrm{C} \mathrm{NMR}$ $(\delta): 112.4$ (C-1), 116.1 (C-5), 124.2 (C-3), 135.9 (C-4), 151.2 (C-6), 163.3 (C-2) and 193.9 (CHO). EI-MS ( $\mathrm{m} / z$, rel. int., \%): 167 $\left(\mathrm{M}^{+}, 7\right), 149$ (39), 137 (61), 120 (25), 119 (25), 109 (19), 107 (13), 92 (59), 91 (32), 93 (11), 81 (100) and 63 (85).

2-Benzyloxy-6-nitrobenzaldehyde (23). $\mathrm{K}_{2} \mathrm{CO}_{3} \quad(560 \quad \mathrm{mg}$, $4.00 \mathrm{mmol}$ ) was added to a solution of nitro-salicylaldehyde 22 (223 mg, $1.334 \mathrm{mmol})$ in EtOH $(3 \mathrm{~mL})$. The mixture was stirred for 10 minutes at room temperature; then benzyl chloride (338 $\mathrm{mg}, 2.67 \mathrm{mmol}$ ) was added dropwise and the mixture was stirred overnight at $70{ }^{\circ} \mathrm{C}$. After confirming the complete consumption of the starting material, the solvent was evaporated under reduced pressure and the residue was diluted with brine $(10 \mathrm{~mL})$ and $1 \mathrm{M} \mathrm{NaOH}(10 \mathrm{~mL})$. The product was extracted with EtOAc $(3 \times 20 \mathrm{~mL})$; the combined organic extracts were washed with water $(10 \mathrm{~mL})$, dried over $\mathrm{Na}_{2} \mathrm{SO}_{4}$, concentrated and filtered through a short path of a silica gel to yield the benzyl ether derivative 23 (342 $\mathrm{mg}, 99 \%)$ as a yellowish oil. ${ }^{38}$ IR (film, $\nu$ ): 3734, 3250, 1646, 1626, 1578, 1368, 1340, 1283, 1153, 1081, 1010, 842 and $669 \mathrm{~cm}^{-1} .{ }^{1} \mathrm{H}$ NMR $(\delta): 5.22(\mathrm{~s}, 2 \mathrm{H}$, $\mathrm{OCH}_{2} \mathrm{Ar}$ ), 7.29 (d, $\left.1 \mathrm{H}, J=8.1, \mathrm{H}-3\right), 7.36-7.41$ (m, 5H, ArH of benzyl), 7.45 (d, 1H, $J=8.1, \mathrm{H}-5), 7.56(\mathrm{t}, 1 \mathrm{H}, J=8.1, \mathrm{H}-4)$ and $10.40(\mathrm{~s}, 1 \mathrm{H}, \mathrm{CHO}) .{ }^{13} \mathrm{C} \mathrm{NMR}(\delta): 71.6\left(\mathrm{OCH}_{2} \mathrm{Ar}\right), 115.9(\mathrm{C}-5)$, 117.6 (C-3), 121.2 (C-1), 127.2 (C-1' and C-6'), 128.6 (C-4'), 128.9 (C-3' and C-5'), 133.4 (C-4), 135.0 (C-1'), 148.7 (C-3), 158.8 (C-2) and $187.6(\mathrm{CHO})$.

Ethyl $\quad E-3-(2 '$-benzyloxy-6'-nitrophenyl)acrylate $\quad(E-24)$. A mixture of aldehyde 23 (265 mg, $1.03 \mathrm{mmol}$ ) and ethyl (triphenyl- $\lambda 5$-phosphanylidene)-acetate $(1180 \mathrm{mg}, 2.06 \mathrm{mmol})$ in dichloromethane $(3 \mathrm{~mL})$ was stirred at room temperature for $5 \mathrm{~h}$. Once the complete consumption of the starting material was confirmed by TLC, the solvent was removed under reduced pressure and the residue was chromatographed, affording $\boldsymbol{E}-24$ (297 $\mathrm{mg}, 88 \%)$ as a yellow solid, m.p.: $80-82{ }^{\circ} \mathrm{C}$. IR (KBr, $\nu$ ): 1705, 1521, 1350, 1288, 1273, 1193, 1041, 840 and $746 \mathrm{~cm}^{-1}$. ${ }^{1} \mathrm{H}$ NMR $(\delta): 1.32\left(\mathrm{t}, 3 \mathrm{H}, J=7.1, \mathrm{OCH}_{2} \mathrm{CH}_{3}\right), 4.25$ $\left(\mathrm{q}, 2 \mathrm{H}, J=7.1, \mathrm{OCH}_{2} \mathrm{CH}_{3}\right), 5.22\left(\mathrm{~s}, 2 \mathrm{H}, \mathrm{OCH}_{2} \mathrm{Ar}\right), 6.58(\mathrm{~d}, 1 \mathrm{H}$, $\left.J=16.2, \mathrm{CH}=\mathrm{CHCO}_{2} \mathrm{Et}\right), 7.16(\mathrm{dd}, 1 \mathrm{H}, J=2.0$ and 8.0, H-3), 
$7.35(\mathrm{dt}, 1 \mathrm{H}, J=2.0$ and 8.0, H-5), $7.36(\mathrm{~d}, J=8.0,1 \mathrm{H}, \mathrm{H}-4)$, 7.38-7.41 (m, 5H, ArH of benzyl) and $7.73(\mathrm{~d}, 1 \mathrm{H}, J=$ 16.2, $\left.\mathrm{CH}=\mathrm{CHCO}_{2} \mathrm{Et}\right) .{ }^{13} \mathrm{C} \mathrm{NMR}(\delta): 14.3\left(\mathrm{OCH}_{2} \mathrm{CH}_{3}\right), 60.7$ $\left(\mathrm{OCH}_{2} \mathrm{CH}_{3}\right), 71.4\left(\mathrm{OCH}_{2} \mathrm{Ar}\right), 116.3(\mathrm{C}-3), 116.5(\mathrm{C}-5), 118.7$ (C-1), $125.9\left(\mathrm{CH}=\mathrm{CHCO}_{2} \mathrm{Et}\right), 127.0$ (benzyl), 128.4 (C-4), 128.6 (benzyl), 128.8 (benzyl), $134.3\left(\mathrm{CH}=\mathrm{CHCO}_{2} \mathrm{Et}\right), 135.5$ (benzyl), 150.9 (C-6), 157.5 (C-2) and 166.4 ( $\left.\mathrm{CH}=\mathrm{CHCO}_{2} \mathrm{Et}\right)$. HRMS $\mathrm{m} / \mathrm{z}$ calcd for $\mathrm{C}_{18} \mathrm{H}_{18} \mathrm{NO}_{5}: 328.1185[\mathrm{M}+\mathrm{H}]^{+}$; found: 328.1179.

Ethyl Z-3-(2-benzyloxy-6-nitrophenyl)-3-(4'-methoxyphenyl)acrylate (26). A mixture of cinnamate ester 24 (245 mg, $0.749 \mathrm{mmol})$ and $\mathrm{Pd}(\mathrm{OAc})_{2}(17 \mathrm{mg}, 0.0749 \mathrm{mmol})$ in $\mathrm{MeOH}$ $(3 \mathrm{~mL})$ was vigorously stirred at $80^{\circ} \mathrm{C}$ for $30 \mathrm{~s}$; then $p$-anisidine diazonium tetrafluoroborate salt $(333 \mathrm{mg}, 1.50 \mathrm{mmol})$ prepared under the literature-reported conditions ${ }^{24 a}$ was added into one portion. The reaction was further stirred at $80{ }^{\circ} \mathrm{C}$ until the complete consumption of the starting material was confirmed by TLC analysis. Then, the reaction mixture was concentrated under reduced pressure and the residue was chromatographed to afford the $\beta, \beta$-diphenylacrylate 26 (194 mg, 60\%) as a yellow solid, m.p.: 102-104 ${ }^{\circ} \mathrm{C}$. IR (KBr, $\nu$ ): 2934, 1717, 1603, 1526, 1508, 1448, 1362, 1269, 1163 and $741 \mathrm{~cm}^{-1} .{ }^{1} \mathrm{H}$ NMR $(\delta): 1.08\left(\mathrm{t}, 3 \mathrm{H}, J=7.1, \mathrm{OCH}_{2} \mathrm{CH}_{3}\right), 3.82$ $\left(\mathrm{s}, 3 \mathrm{H}, \operatorname{ArOCH}_{3}\right), 3.98$ (q, 2H, $\left.J=7.1, \mathrm{OCH}_{2} \mathrm{CH}_{3}\right), 5.02(\mathrm{q}, 2 \mathrm{H}, J=$ 12.3, $\mathrm{OCH}_{2} \mathrm{Ar}$ ), 6.45 (s, $\left.1 \mathrm{H}, \mathrm{H}-3\right), 6.85$ (d, 2H, $J=8.8, \mathrm{H}-11$ and $\mathrm{H}-13$ ), 7.04 (dd, 2H, $J=2.8$ and 6.3, ArH of benzyl), $7.21(\mathrm{~d}, 1 \mathrm{H}$, $J=8.3, \mathrm{H}-8), 7.23-7.26$ (m, 3H, ArH of benzyl), 7.33 (d, 2H, $J=$ 8.8, H-10 and $\mathrm{H}-14), 7.45(\mathrm{t}, 1 \mathrm{H}, J=8.3, \mathrm{H}-7)$ and $7.72(\mathrm{~d}, 1 \mathrm{H}$, $J=8.3, \mathrm{H}-6) .{ }^{13} \mathrm{C}$ NMR $(\delta): 14.0\left(\mathrm{OCH}_{2} \mathrm{CH}_{3}\right), 55.3\left(\mathrm{OCH}_{3}\right), 60.0$ $\left(\mathrm{OCH}_{2} \mathrm{CH}_{3}\right), 70.8\left(\mathrm{OCH}_{2} \mathrm{Ar}\right), 113.9$ (C-11 and C-13), 116.0 (C-3), $116.4(\mathrm{C}-6),{ }^{*} 117.0$ (C-8), ${ }^{*} 124.9$ (C-1), 126.9 (2C, benzyl), 127.9 (C-4'), 128.4 (2C, benzyl), 128.7 (C-10 and C-14), 129.1 (C-7), 130.6 (C-9), 136.0 (benzyl), 149.0 (C-7), 149.2 (C-6), 155.9 (C-2), $160.8\left(\mathrm{C}-4^{\prime}\right)$ and $165.6\left(\mathrm{CO}_{2} \mathrm{Et}\right)$. EI-MS ( $\mathrm{m} / \mathrm{z}$, rel. int., \%): 433 ( $\left.\mathrm{M}^{+}, 1\right), 416$ (10), 151 (58), 150 (100), 133 (20), 122 (47), 121 (21), 115 (29), 107 (22), 106 (30), 105 (31), 104 (20), 103 (59), 94 (36), 93 (28), 91 (56) and 77 (92). HRMS $m / z$ calcd for $\mathrm{C}_{25} \mathrm{H}_{24} \mathrm{NO}_{6} 434.1604[\mathrm{M}+\mathrm{H}]^{+}$; found: 434.1598 .

5-Benzyloxy-4-(4'-methoxyphenyl)-1H-quinolin-2-one (19). Clean iron turnings $(206 \mathrm{mg}, 3.69 \mathrm{mmol})$ were added to a stirred solution of $\beta, \beta$-diphenylacrylate $26 \quad(200 \mathrm{mg}$, $0.461 \mathrm{mmol})$ in glacial AcOH $(2 \mathrm{~mL})$ pre-heated at $110{ }^{\circ} \mathrm{C}$. Stirring was continued for $18 \mathrm{~h}$; then the solution was brought to room temperature, and the precipitate was filtered off and washed with EtOAc $(10 \mathrm{~mL})$. The combined organic solutions were evaporated under reduced pressure and the residue was chromatographed to furnish $19(120 \mathrm{mg}, 74 \%)$ as a brown solid, m.p.: 207-209 ${ }^{\circ} \mathrm{C}$. IR (KBr, $\nu$ ): 3734, 3250, 1646, 1626, 1578, 1368, 1340, 1283, 1153, 1081, 1010, 842 and $669 \mathrm{~cm}^{-1}$.

${ }^{1} \mathrm{H}$ NMR $(\delta): 3.62\left(\mathrm{~s}, 3 \mathrm{H}, \mathrm{OCH}_{3}\right), 4.69\left(\mathrm{~s}, 2 \mathrm{H}, \mathrm{OCH}_{2} \mathrm{Ar}\right), 6.28$ $(\mathrm{s}, 1 \mathrm{H}, \mathrm{H}-3), 6.57$ (d, $2 \mathrm{H}, J=8.5, \mathrm{H}-3^{\prime}$ and $\left.\left.\mathrm{H}^{-5}\right)^{\prime}\right), 6.57$ (d, $J=8.3$, $1 \mathrm{H}, \mathrm{H}-6), 6.74$ (d, $2 \mathrm{H}, J=8.5, \mathrm{H}-2^{\prime}$ and $\left.\mathrm{H}-6^{\prime}\right), 6.98$ (d, $1 \mathrm{H}, J=$ 8.3, H-8), 7.03-7.14 (m, 5H, ArH of benzyl), 7.30 (t, $1 \mathrm{H}, J=8.3$, $\mathrm{H}-7)$ and $11.71(\mathrm{~s}, 1 \mathrm{H}, \mathrm{N}-H) \cdot{ }^{13} \mathrm{C} \mathrm{NMR}(\delta): 54.9\left(\mathrm{OCH}_{3}\right), 70.5$ $\left(\mathrm{OCH}_{2} \mathrm{Ar}\right), 105.1$ (C-6), 109.5 (C-8), 110.2 (C-4a), 112.5 (C-3' and C-5'), 122.4 (C-3), 127.2 (C-2' and C-6'), 127.5 (benzyl), 127.9 (benzyl), 128.6 (benzyl), 131.1 (C-7), 134.0 (C-1'), 135.7 (benzyl), 140.8 (C-8a), 152.3 (C-4), 156.4 (C-5), 158.8 (C-4') and $162.9(\mathrm{C}-2)$. HRMS $\mathrm{m} / \mathrm{z}$ calcd for $\mathrm{C}_{23} \mathrm{H}_{19} \mathrm{NNaO}_{3}: 380.1257$ $[\mathrm{M}+\mathrm{Na}]^{+}$; found: 380.1245 .

5-Hydroxy-4-(4'-methoxyphenyl)-1H-quinolin-2-one (27). Method $A$ : the benzyloxy derivative $19(62 \mathrm{mg}, 0.174 \mathrm{mmol})$ was added to a stirred suspension of $10 \% \mathrm{Pd} / \mathrm{C}(3 \mathrm{mg})$ in a $1: 1$ mixture of EtOH : EtOAc $(2 \mathrm{~mL})$, and cooled to $0{ }^{\circ} \mathrm{C}$ in an ice bath. The system was placed under a hydrogen atmosphere (1 atm.) and stirred for $4 \mathrm{~h}$. Then, the reaction was diluted with EtOAc $(10 \mathrm{~mL})$ and filtered through Celite. The filtrate was dried over $\mathrm{Na}_{2} \mathrm{SO}_{4}$, concentrated in vacuo and chromatographed, affording the 5-hydroxy-1H-quinolin-2-one 27 (41 mg, 89\%) as a tan crystalline solid, m.p.: 260-262 ${ }^{\circ} \mathrm{C}$ (hexanes-EtOAc). IR (KBr, $\nu$ ): 2928, 2369, 1630, 1607, 1508, 1356, 1281, 1244 and $833 \mathrm{~cm}^{-1} .{ }^{1} \mathrm{H}$ NMR $(\delta): 3.89\left(\mathrm{~s}, 3 \mathrm{H}, \mathrm{OCH}_{3}\right), 5.59(\mathrm{~s}, 1 \mathrm{H}, \mathrm{N}-H)$, 6.41 (s, 1H, H-3), 6.64 (dd, $1 \mathrm{H}, J=0.7$ and 8.3, H-6), 6.98 (dd, $1 \mathrm{H}, J=0.7$ and 8.3, H-8), $7.06\left(\mathrm{~d}, 2 \mathrm{H}, J=8.7, \mathrm{H}-3^{\prime}\right.$ and $\left.\mathrm{H}-5^{\prime}\right)$, $7.39(\mathrm{t}, 1 \mathrm{H}, J=8.3, \mathrm{H}-7), 7.41\left(\mathrm{~d}, 2 \mathrm{H}, J=8.7, \mathrm{H}-2^{\prime}\right.$ and $\left.\mathrm{H}-6^{\prime}\right)$ and $8.53(\mathrm{~s}, 1 \mathrm{H}, \mathrm{OH}) .{ }^{13} \mathrm{C} \mathrm{NMR}(\delta): 55.5\left(\mathrm{OCH}_{3}\right), 108.3(\mathrm{C}-4 \mathrm{a}), 108.7$ (C-6), 110.4 (C-8), 115.0 (C-3' and C-5'), 121.8 (C-3), 129.4 (C-2' and C-6'), 129.6 (C-1'), 132.1 (C-7), 139.9 (C-8a), 150.2 (C-4), 154.3 (C-5), 160.7 (C-12), and 163.0 (C-2). EI-MS ( $\mathrm{m} / \mathrm{z}$, rel. int., $\%): 357\left(\mathrm{M}^{+}, 6\right), 91$ (100), 73 (14) and 71 (18). HRMS $\mathrm{m} / \mathrm{z}$ calcd for $\mathrm{C}_{16} \mathrm{H}_{14} \mathrm{NO}_{3}$ : $268.0974[\mathrm{M}+\mathrm{H}]^{+}$; found: 268.0968 .

Method B: a magnetically stirred mixture of compound 26 (24 mg, $0.055 \mathrm{mmol}$ ) and $10 \% \mathrm{Pd} / \mathrm{C}(1 \mathrm{mg})$ in anhydrous $\mathrm{MeOH}(2 \mathrm{~mL})$ was exposed to a hydrogen atmosphere (1 atm.) for $2 \mathrm{~h}$ at room temperature. Then, the suspension was filtered through a short pad of Celite and the filtrate was concentrated under reduced pressure. The ensuing light yellow solid was subjected to flash chromatography, affording compound 27 (4 mg, 30\%) as a brownish crystalline solid. The spectral data of this product were in full agreement with those recorded for the product obtained through Method A.

5-Allyloxy-4-(4'-methoxyphenyl)-1H-quinolin-2-one (31). A solution of 27 (316 mg, $1.183 \mathrm{mmol})$ in absolute EtOH (4 mL) was treated with $\mathrm{K}_{2} \mathrm{CO}_{3}(199 \mathrm{mg}, 1.420 \mathrm{mmol})$. The resulting suspension was stirred at room temperature for $10 \mathrm{~min}$; then allyl bromide (171 mg, $1.420 \mathrm{mmol}$ ) was added into one portion and the reaction was heated under reflux for $4 \mathrm{~h}$. After confirming the complete consumption of the starting material by TLC, the reaction mixture was treated with a $1 \mathrm{M}$ solution of $\mathrm{HCl}(10 \mathrm{~mL})$ and the products were extracted with EtOAc $(3 \times 15 \mathrm{~mL})$. The combined extracts were dried with $\mathrm{Na}_{2} \mathrm{SO}_{4}$ and concentrated under reduced pressure. The residue was subjected to flash chromatography, affording compound 31 (235 mg, 65\%) as a colorless solid, m.p.: $210-212{ }^{\circ} \mathrm{C}\left(\mathrm{CH}_{2} \mathrm{Cl}_{2}\right)$. IR (ATR, $\nu$ ): 3734, 3250, 1646, 1626, 1578, 1368, 1340, 1283, 1153, 1081, 1010, 842 and $669 \mathrm{~cm}^{-1} .{ }^{1} \mathrm{H}$ NMR (DMSO- $d_{6}, \delta$ ): $3.77\left(\mathrm{~s}, 3 \mathrm{H}, \mathrm{OCH}_{3}\right), 4.25$ (d, $J=5.2,2 \mathrm{H}, \mathrm{CH}_{2}=\mathrm{CH}-\mathrm{CH}_{2}-\mathrm{Ar}$ ), $4.79\left(\mathrm{~d}, J=18.7,1 \mathrm{H}, \mathrm{CH}_{\text {trans }}=\mathrm{CH}-\mathrm{CH}-\mathrm{Ar}\right), 4.90(\mathrm{~d}, J=10.7,1 \mathrm{H}$, $\mathrm{CH}_{\text {cis }}=\mathrm{CH}-\mathrm{CH}_{2}-\mathrm{Ar}$ ), 5.36 (ddd, $J=5.2,10.7$ and $18.7,1 \mathrm{H}$, $\left.\mathrm{CH}_{2}=\mathrm{CH}-\mathrm{CH}_{2}-\mathrm{Ar}\right), 5.59(\mathrm{~s}, 1 \mathrm{H}, \mathrm{NH}), 6.41(\mathrm{~s}, 1 \mathrm{H}, \mathrm{H}-3), 6.66$ (d, $1 \mathrm{H}, J=8.2, \mathrm{H}-6), 6.89\left(\mathrm{~d}, 2 \mathrm{H}, J=8.5, \mathrm{H}-3^{\prime}\right.$ and $\left.\mathrm{H}-5^{\prime}\right), 6.97$ (d, $1 \mathrm{H}, J=8.2, \mathrm{H}-8), 7.17$ (d, $2 \mathrm{H}, J=8.5, \mathrm{H}-2^{\prime}$ and $\left.\mathrm{H}-6^{\prime}\right)$, and $7.41(\mathrm{t}, 1 \mathrm{H}, J=8.2, \mathrm{H}-7) .{ }^{13} \mathrm{C}$ NMR (DMSO- $\left.d_{6}, \delta\right): 55.5\left(\mathrm{OCH}_{3}\right)$, 
$69.2\left(\mathrm{CH}_{2}=\mathrm{CH}-\mathrm{CH}_{2}-\mathrm{Ar}\right), 108.3$ (C-4a), 108.7 (C-6), 110.4 (C-8), 115.0 (C-3' and C-5'), $117.1\left(\mathrm{CH}_{2}=\mathrm{CH}-\mathrm{CH}-\mathrm{Ar}\right), 121.8$ (C-3), 129.4 (C-2' and C-6'), 129.6 (C-9), 132.1 (C-7), $132.8\left(\mathrm{CH}_{2}=\mathrm{CH}-\right.$ CH-Ar), 139.9 (C-8a), 150.2 (C-4), 154.3 (C-5), 160.7 (C-12) and 163.0 (C-2). HRMS $m / z$ for $\mathrm{C}_{19} \mathrm{H}_{18} \mathrm{NO}_{3}$ : $308.1287[\mathrm{M}+\mathrm{H}]^{+}$; found: 308.1281 .

6-Allyl-5-hydroxy-4-(4'-methoxyphenyl)-1H-quinolin-2-one (32). The $O$-allyl derivative (31) (200 $\mathrm{mg}, 0.651 \mathrm{~s} \mathrm{mmol}$ ) was dissolved in 1,2-dichlorobenzene ( $4 \mathrm{~mL}$ ) and the solution was placed in a sealed tube. The mixture was heated in a microwave reactor $(300 \mathrm{~W})$ at $190{ }^{\circ} \mathrm{C}$ for $120 \mathrm{~min}$. The crude product was purified by flash chromatography on a silica gel to give 32 $(0.150 \mathrm{~g}, 75 \%)$ as a colorless oil, m.p.: $>300{ }^{\circ} \mathrm{C}$ (EtOAc). IR (KBr, $\nu$ ): 2928, 2369, 1630, 1607, 1508, 1356, 1281, 1244 and $833 \mathrm{~cm}^{-1} .{ }^{1} \mathrm{H}$ NMR $(\delta): 3.33\left(\mathrm{~d}, 2 \mathrm{H}, J=6.5, \mathrm{H}-1^{\prime}\right), 3.89(\mathrm{~s}, 3 \mathrm{H}$, $\left.\mathrm{OCH}_{3}\right), 4.99\left(\mathrm{~d}, J=15.7,1 \mathrm{H}, \mathrm{CH}_{c i s}=\mathrm{CH}-\mathrm{CH}_{2}-\mathrm{Ar}\right), 5.04(\mathrm{~d}, J=$ 17.8, $\left.1 \mathrm{H}, \mathrm{CH}_{\text {trans }}=\mathrm{CH}-\mathrm{CH}_{2}-\mathrm{Ar}\right), 5.93(\mathrm{ddd}, 1 \mathrm{H}, J=6.5,15.7$ and 17.8, $\left.\mathrm{CH}_{2}=\mathrm{CH}-\mathrm{CH}_{2}-\mathrm{Ar}\right), 6.41(\mathrm{~s}, 1 \mathrm{H}, \mathrm{H}-3), 6.99$ (d, 1H, $J=$ 8.3, H-8), 7.06 (d, 2H, $J=8.7, \mathrm{H}-3^{\prime}$ and $\mathrm{H}-5^{\prime}$ ), 7.30 (d, $1 \mathrm{H}, J=$ 8.3, H-7) and $7.40\left(\mathrm{~d}, 2 \mathrm{H}, J=8.7, \mathrm{H}-2^{\prime}\right.$ and $\left.\mathrm{H}-6{ }^{\prime}\right) .{ }^{13} \mathrm{C} \operatorname{NMR}(\delta)$ : $34.0\left(\mathrm{CH}_{2}=\mathrm{CH}-\mathrm{CH}_{2}-\mathrm{Ar}\right), 55.4\left(\mathrm{OCH}_{3}\right), 108.2$ (C-4a), 108.4 (C-8), 115.0 (C-3' and C-5'), $115.6\left(\mathrm{CH}_{2}=\mathrm{CH}-\mathrm{CH}_{2}-\mathrm{Ar}\right), 120.6$ (C-8a), 121.9 (C-3), 129.5 (C-2' and C-6'), 129.7 (C-1'), 133.3 (C-7), $136.5\left(\mathrm{CH}_{2}=\mathrm{CH}-\mathrm{CH}_{2}-\mathrm{Ar}\right), 138.6$ (C-6), 150.2 (C-4), 151.3 (C-5), 160.7 (C-4') and 163.1 (C-2). HRMS $\mathrm{m} / \mathrm{z}$ calcd for $\mathrm{C}_{19} \mathrm{H}_{18} \mathrm{NO}_{3} 308.1287[\mathrm{M}+\mathrm{H}]^{+}$; found: 308.1281.

5-Hydroxy-4-(4'-methoxyphenyl)-6-(3-methyl-but-2-enyl)-1Hquinolin-2-one (33). To a stirred solution of the allyl derivative 32 (12 mg, $0.039 \mathrm{mmol})$ in anhydrous $\mathrm{CH}_{2} \mathrm{Cl}_{2}(0.5 \mathrm{~mL})$ was added the Grubbs II catalyst (1.6 mg, $5 \mathrm{~mol} \%)$. Then, 2-methyl-but-2-ene (27.4 mg, $0.391 \mathrm{mmol}$ ) was added dropwise, the system was sealed and the mixture was heated to reflux. After being stirred for $2 \mathrm{~h}$, the reaction was cooled to $\mathrm{rt}$ and filtered through a silica plug, washing with EtOAc $(20 \mathrm{~mL})$. The filtrate was concentrated under reduced pressure to afford 33 (10 mg, 77\%) as a brownish solid, m.p.: 222-224 ${ }^{\circ} \mathrm{C}$ (EtOAc). IR (KBr, $\nu$ ): 3480, 2926, 2359, 1645, 1634, 1607, 1512, 1454, 1373, 1248, 1178, 1032 and $833 \mathrm{~cm}^{-1}$.

${ }^{1} \mathrm{H}$ NMR $(\delta): 1.67\left(\mathrm{~s}, 3 \mathrm{H}, \mathrm{C}-\mathrm{CH}_{3}\right), 1.71$ (s, 3H, C-CH $\left.\mathrm{CH}_{3}\right), 3.25$ $\left[\mathrm{d}, 1 \mathrm{H}, \mathrm{J}=6.7, \mathrm{CH}_{2}-\mathrm{CH}=\mathrm{C}\left(\mathrm{CH}_{3}\right)_{2}\right], 3.89\left(\mathrm{~s}, 3 \mathrm{H}, \mathrm{OCH}_{3}\right), 5.24$ [bs, $\left.1 \mathrm{H}, \mathrm{CH}_{2}-\mathrm{CH}=\mathrm{C}\left(\mathrm{CH}_{3}\right)_{2}\right], 5.67$ (bs, $\left.1 \mathrm{H},-\mathrm{NH}\right), 6.39(\mathrm{~s}, 1 \mathrm{H}$, $\mathrm{H}-3$ ), 6.94 (d, $1 \mathrm{H}, J=8.2, \mathrm{H}-8), 7.07$ (d, 2H, $J=8.3, \mathrm{H}-3^{\prime}$ and H-5') 7.29 (d, $1 \mathrm{H}, J=8.2, \mathrm{H}-7), 7.40$ (d, 2H, $J=8.3, \mathrm{H}-2^{\prime}$ and $\left.\mathrm{H}-6^{\prime}\right)$ and $11.91(\mathrm{~s}, 1 \mathrm{H}, \mathrm{OH}) .{ }^{13} \mathrm{C} \mathrm{NMR}(\delta): 17.8\left(\mathrm{C}-\mathrm{CH}_{3}\right), 25.7$ $\left(\mathrm{C}-\mathrm{CH}_{3}\right), 28.2\left[\mathrm{CH}_{2}-\mathrm{CH}=\mathrm{C}\left(\mathrm{CH}_{3}\right)_{2}\right], 55.4\left(\mathrm{OCH}_{3}\right), 108.2(\mathrm{C}-8)$, 115.0 (C-3' and C-5'), 122.1 (C-3), $122.2\left[\mathrm{CH}_{2}-\mathrm{CH}=\mathrm{C}\left(\mathrm{CH}_{3}\right)_{2}\right]$, 127.3 (C-4a), 128.7 (C-4), 129.5 (C-2' and C-6'), 129.9 (C-9), $132.9(\mathrm{C}-7), 133.2\left[\mathrm{CH}_{2}-\mathrm{CH}=C\left(\mathrm{CH}_{3}\right)_{2}\right], 138.2(\mathrm{C}-8 \mathrm{a}), 150.2$ (C-6), 151.3 (C-5), 160.6 (C-4') and 163.0 (C-2). HRMS $\mathrm{m} / \mathrm{z}$ calcd for $\mathrm{C}_{21} \mathrm{H}_{22} \mathrm{NO}_{3}$ : $336.1577[\mathrm{M}+\mathrm{H}]^{+}$; found: 336.1594.

tert-Butyl 6-allyl-5-hydroxy-4-(4'-methoxyphenyl)-2-oxo-2Hquinoline-1-carboxylate (35). To a solution of 32 (146 mg, $0.475 \mathrm{mmol})$ in anhydrous $\mathrm{CH}_{2} \mathrm{Cl}_{2}(2 \mathrm{~mL})$ was added anhydrous $\mathrm{Et}_{3} \mathrm{~N}(144 \mathrm{mg}, 1.425 \mathrm{mmol})$ and DMAP (17.3 mg, $0.142 \mathrm{mmol})$. Then, $\mathrm{Boc}_{2} \mathrm{O}(310 \mathrm{mg}, 1.425 \mathrm{mmol})$ was added into one portion and the resulting mixture was stirred at room temperature for $20 \mathrm{~h}$. After the complete consumption of the starting material was confirmed by TLC, the reaction was poured on $\mathrm{H}_{2} \mathrm{O}(10 \mathrm{~mL})$, and the product was extracted with $\mathrm{Et}_{2} \mathrm{O}(3 \times 10 \mathrm{~mL})$. The organic phase was washed with $\mathrm{NaHCO}_{3}$ $(10 \mathrm{~mL})$, brine $(10 \mathrm{~mL})$, and $\mathrm{H}_{2} \mathrm{O}(10 \mathrm{~mL})$. The combined organic layers were dried $\left(\mathrm{Na}_{2} \mathrm{SO}_{4}\right)$ and concentrated under reduced pressure. Chromatography of the residue afforded the compound 35 (120 mg, $0.299 \mathrm{mmol})$ as a pale yellow solid, m.p.: $172-174{ }^{\circ} \mathrm{C}\left(\mathrm{CH}_{2} \mathrm{Cl}_{2}\right)$. IR (KBr, $\left.\nu\right): 2930,1666,1661,1514$, 1371, 1101, 876 and $833 \mathrm{~cm}^{-1} .{ }^{1} \mathrm{H}$ NMR $(\delta): 1.26(\mathrm{~s}, 9 \mathrm{H}$, $\left.\mathrm{C}-\left(\mathrm{CH}_{3}\right)_{3}\right), 3.28\left(\mathrm{~d}, 2 \mathrm{H}, J=6.5, \mathrm{CH}_{2}-\mathrm{CH}=\mathrm{CH}_{2}\right), 3.88(\mathrm{~s}, 3 \mathrm{H}$, $\left.\mathrm{OCH}_{3}\right), 5.03\left(\mathrm{~m}, 1 \mathrm{H}, \mathrm{CH}_{\text {cis }}=\mathrm{CH}-\mathrm{CH}_{2}-\mathrm{Ar}\right), 5.08(\mathrm{~m}, 1 \mathrm{H}$, $\mathrm{CH}_{\text {trans }}=\mathrm{CH}-\mathrm{CH}_{2}-\mathrm{Ar}$ ), 5.85 (ddd, $1 \mathrm{H}, J=6.5,9.4$ and 16.2, $\mathrm{CH}_{2}=\mathrm{CH}-\mathrm{CH}_{2}-\mathrm{Ar}$ ), 6.54 (s, $\left.1 \mathrm{H}, \mathrm{H}-3\right), 6.97$ (d, 2H, $J=8.6, \mathrm{H}-3^{\prime}$ and $\left.\mathrm{H}-5^{\prime}\right), 7.32\left(\mathrm{~d}, 2 \mathrm{H}, J=8.6, \mathrm{H}-2^{\prime}\right.$ and $\left.\mathrm{H}-6^{\prime}\right), 7.36(\mathrm{~d}, 1 \mathrm{H}, J=$ 8.6, H-8) and $7.42(\mathrm{~d}, 1 \mathrm{H}, J=8.6, \mathrm{H}-7) .{ }^{13} \mathrm{C} \operatorname{NMR}(\delta): 27.3$ $\left[\mathrm{C}-\left(\mathrm{CH}_{3}\right)_{3}\right], \quad 33.7 \quad\left(\mathrm{CH}_{2}=\mathrm{CH}-\mathrm{CH}_{2}-\mathrm{Ar}\right), \quad 55.3 \quad\left(\mathrm{OCH}_{3}\right), \quad 83.3$ $\left[\mathrm{C}-\left(\mathrm{CH}_{3}\right)_{3}\right], 104.3$ (C-6), 113.4 (C-9), 113.6 (C-3' and C-5'), 115.0 (C-8), $116.8\left(\mathrm{CH}_{2}=\mathrm{CH}-\mathrm{CH}_{2}-\mathrm{Ar}\right), 124.0$ (C-3), 127.5 (C-3), 131.8 (C-4a), 132.5 (C-2' and C-6'), $135.4\left(\mathrm{CH}_{2}=\mathrm{CH}-\mathrm{CH}_{2}-\mathrm{Ar}\right), 138.8$ (C-8a), 143.2 (C-5), 150.4 [N-(C=O)-O], 151.0 (C-4), 159.4 (C-4') and 163.2 (C-2). HRMS $m / z$ calcd for $\mathrm{C}_{24} \mathrm{H}_{25} \mathrm{NNaO}_{5}: 430.1625$ $[\mathrm{M}+\mathrm{Na}]^{+}$; found: 430.1610 .

tert-Butyl 5-hydroxy-4-(4'-methoxyphenyl)-2-oxo-6-propenyl$1 \mathrm{H}$-quinoline-1-carboxylate (36). To a solution of allyl derivative 35 (10 mg, $0.024 \mathrm{mmol})$ in EtOH (1 mL) was added $\mathrm{RhCl}_{3} \cdot 3 \mathrm{H}_{2} \mathrm{O}(2.13 \mathrm{mg}, 0.0082 \mathrm{mmol})$. The resulting mixture was stirred for $31 \mathrm{~h}$ at room temperature. Then, the reaction was filtered through a silica-pad with EtOAc as an eluent. The filtrate was concentrated under reduced pressure to afford compound 36 (5 mg, 50\%) as a white solid, m.p.: $139-140{ }^{\circ} \mathrm{C}$ $\left(\mathrm{CH}_{2} \mathrm{Cl}_{2}\right)$. IR (KBr, $\nu$ ): 3690, 2928, 2853, 2370, 1751, 1663, 1549, 1508, 1458, 1248, 1151 and $833 \mathrm{~cm}^{-1} .{ }^{1} \mathrm{H}$ NMR $(\delta): 1.18[\mathrm{~s}, 9 \mathrm{H}$, $\left.\mathrm{C}-\left(\mathrm{CH}_{3}\right)_{3}\right], 1.78\left(\mathrm{~d}, 3 \mathrm{H}, J=6.3, \mathrm{CH}_{3}-\mathrm{CH}=\mathrm{CH}-\mathrm{Ar}\right), 3.80(\mathrm{~s}, 3 \mathrm{H}$, $\left.\mathrm{OCH}_{3}\right), 6.19\left(\mathrm{dd}, J=6.3\right.$ and $15.7,1 \mathrm{H}, \mathrm{CH}_{3}-\mathrm{CH}=\mathrm{CH}-\mathrm{Ar}$ ), $6.36\left(\mathrm{~d}, J=15.7,1 \mathrm{H}, \mathrm{CH}_{3}-\mathrm{CH}=\mathrm{CH}-\mathrm{Ar}\right), 6.53(\mathrm{~s}, 1 \mathrm{H}, \mathrm{H}-3)$, $6.95\left(\mathrm{~d}, 2 \mathrm{H}, J=8.6, \mathrm{H}-3^{\prime}\right.$ and $\left.\mathrm{H}-5^{\prime}\right), 7.19\left(\mathrm{~d}, 2 \mathrm{H}, J=8.6, \mathrm{H}-2^{\prime}\right.$ and $\left.\mathrm{H}-6^{\prime}\right), 7.28(\mathrm{~d}, 1 \mathrm{H}, J=8.8, \mathrm{H}-7)$ and $8.73(\mathrm{~d}, 1 \mathrm{H}, J=$ 8.8, H-8). ${ }^{13} \mathrm{C}$ NMR (DMSO- $\left.d_{6}, \delta\right): 18.6\left(\mathrm{CH}_{3}-\mathrm{CH}=\mathrm{CH}-\mathrm{Ar}\right)$, $26.8\left[\mathrm{C}-\left(\mathrm{CH}_{3}\right)_{3}\right], 55.1\left(\mathrm{OCH}_{3}\right), 82.5\left[\mathrm{C}-\left(\mathrm{CH}_{3}\right)_{3}\right], 112.3(\mathrm{C}-6)$, 113.2 (C-3' and C-5'), $114.2(\mathrm{C}-7), 123.2\left(\mathrm{CH}_{3}-\mathrm{CH}=\mathrm{CH}-\mathrm{Ar}\right)$, 124.3 (C-3), 124.5 (C-4a), $127.9 \quad\left(\mathrm{CH}_{3}-\mathrm{CH}=\mathrm{CH}-\mathrm{Ar}\right), 128.5$ (C-8), 129.1 (C-2' and C-6'), 131.4 (C-9), 139.5 (C-8a), 143.2 $(\mathrm{N}(\mathrm{C}=\mathrm{O})-\mathrm{O}), 149.3(\mathrm{C}-4), 149.8(\mathrm{C}-5), 158.8\left(\mathrm{C}-4^{\prime}\right)$ and 160.4 (C-2). HRMS $m / z$ calcd for $\mathrm{C}_{24} \mathrm{H}_{25} \mathrm{NNaO}_{5}$ : $430.1625[\mathrm{M}+\mathrm{H}]^{+}$; found: 430.1609 .

\section{Acknowledgements}

The authors are thankful to Consejo Nacional de Investigaciones Científicas y Técnicas (CONICET) and Agencia Nacional de Promoción Científica y Tecnológica (ANPCyT) for financial support (PIP no. 2012-0471 and PICTs no. 2011-0399 and 2014-0445). S.O.S. also acknowledges CONICET for his fellowship. 


\section{Notes and references}

1 (a) R. W. DeSimone, K. S. Currie, S. A. Mitchell, J. W. Darrow and D. A. Pippin, Comb. Chem. High Throughput Screening, 2004, 7, 473-494; (b) D. A. Horton, G. T. Bourne and M. L. Smythe, Chem. Rev., 2003, 103, 893930; (c) A. Méndez-Vilas, Science Against Microbial Pathogens: Communicating Current Research and Technological Advances, Formatex, Badajoz, Spain, 2011, vol. 2; (d) S. Bongarzone and M. L. Bolognesi, Exp. Opin. Drug Discov., 2011, 6, 251-268; (e) V. R. Solomon and H. Lee, Curr. Med. Chem., 2011, 18, 1488-1508; (f) R. Musiol, Curr. Pharm. Des., 2013, 19, 1835-1849; (g) J. Klekota and F. P. Roth, Bioinformatics, 2008, 24, 2518-2525.

2 (a) K. Scherlach and C. Hertweck, Org. Biomol. Chem., 2006, 4, 3517-3520; (b) J. P. Michael, Nat. Prod. Rep., 2003, 20, 476-493.

3 (a) R. Uchida, R. Imasato, Y. Yamaguchi, R. Masuma, K. Shiomi, H. Tomoda and S. Omura, J. Antibiot., 2006, 59, 646-651; (b) J. He, U. Lion, I. Sattler, F. A. Gollmic, S. Grabley, J. Cai, M. Meiners, H. Schünke, K. Schaumann, U. Dechert and M. Krohn, J. Nat. Prod., 2005, 68, 13971399; (c) H. Hayashi, T. Nakatani, Y. Inoue, M. Nakayama and H. Nozaki, Biosci. Bootechnol. Biochem., 1997, 61, 914916; (d) M. Kusano, H. Koshino, J. Uzawa, S. Fujioka, T. Kawano and Y. Kimura, Biosci. Biotechnol. Biochem., 2000, 64, 2559-2568; (e) Y. Kimura, M. Kusano, H. Koshino, J. Uzawa, S. Fujioka and K. Tani, Tetrahedron Lett., 1996, 37, 4961-4964; ( $f$ ) S. G. Wubshet, N. T. Nyberg, M. V. Tejesvi, A. M. Pirttilä, M. Kajula, S. Mattila and D. Staerk, J. Chromatogr. A, 2013, 1302, 34-39; (g) T. O. Larsen, J. Smedsgaard, J. C. Frisvad, U. Anthoni and C. Christophersen, Biochem. Syst. Ecol., 1999, 27, 329332.

4 (a) G. Schmeda-Hirschmann, E. Hormazabal, L. Astudillo, J. Rodriguez and C. Theoduloz, World J. Microbiol. Biotechnol., 2005, 21, 27-32; (b) R. Uchida, R. Imasato, K. Shiomi, H. Tomoda and S. Omura, Org. Lett., 2005, 7, 5701-5704; (c) R. Uchida, R. Imasato, H. Tomoda and S. Omura, J. Antibiotics, 2006, 59, 652-658.

5 (a) S. A. Neff, S. U. Lee, Y. Asami, J. S. Ahn, H. Oh, J. Baltrusaitis, J. B. Gloer and D. T. Wicklow, J. Nat. Prod., 2012, 75, 464-472; (b) C.-Y. An, X.-M. Li, H. Luo, C.-S. Li, M.-H. Wang, G.-M. Xu and B.-G. Wang, J. Nat. Prod., 2013, 76, 1896-1901; (c) M. Chen, C.-L. Shao, H. Meng, Z.-G. She and C.-Y. Wang, J. Nat. Prod., 2014, 77, 2720-2722; (d) J. Framm, L. Nover, A. El-Azzouny, H. Richter, K. Winter and S. Werner, Eur. J. Biochem., 1973, 37, 78-85; (e) L. Nover and M. Luckner, Eur. J. Biochem., 1969, 10, 268-273; $(f)$ L. Rahbæk, J. Breinholt, J. C. Frisvad and C. Christophersen, J. Org. Chem., 1999, 64, 16891692; (g) C. T. Walsh, S. W. Haynes, B. D. Ames, X. Gao and Y. Tang, ACS Chem. Biol., 2013, 8, 1366-1382; (h) Y. Zou, Z. Zhan, D. Li, M. Tang, R. A. Cacho, K. Watanabe and Y. Tang, J. Am. Chem. Soc., 2015, 137, 4980-4983.
6 (a) U. Roos, D. Blaser and C. Epe, Patent EP, 600, 2010; (b) C. Kempter, U. Roos, S. Schorderet Weber, Y. Ebinger and S. Glaser, Patent WO, 060015, 2009; (c) C. Kempter, U. Roos, D. Blaser and C. Epe, Patent WO, 128095, 2010; (d) H. Tomoda, R. Masuma, S. Omura and K. Kobayashi, Patent WO, 059400, 2006; (e) K. Scherlach, H.-M. Dahse and C. Hertweck, Patent DE, 102006006893, 2007; $(f)$ X. Li, X. Huo, J. Li, X. She and X. Pan, Chin. J. Chem., 2009, 27, 1379-1381; $(g)$ H. Ueki, T. K. Ellis, M. A. Khan and V. A. Soloshonok, Tetrahedron, 2003, 59, 7301-7306.

7 (a) E. V. Babaev, Chem. Heterocycl. Compd., 1993, 9, 801822; (b) D. S. Choi, J. H. Kim, J. Y. Lee, U. S. Shin, C. E. Song and M. Y. Yoon, Adv. Synth. Catal., 2007, 349, 1725-1737; (c) T. S. Bugni, C. M. Ireland and D. V. LaBarbera, J. Org. Chem., 2007, 72, 8501-8505; (d) K. Nakamura, T. Shibuya and K. Tanaka, Beilstein J. Org. Chem., 2011, 7, 944-950; (e) L.-P. Guan, F.-N. Li, Z.-S. Quan, L.-P. Guan, Q.-H. Jin, Z.-S. Quan, S.-F. Wang and Z.-S. Quan, Arch. Pharm., 2008, 341, 774-779; (f) S. Y. Choung, C. E. Song, D.-U. Jung, S.-G. Lee and E. J. Roh, Angew. Chem., Int. Ed., 2004, 43, 6183-6185; (g) C. H. Heathcock and B. G. Szczepankiewicz, J. Org. Chem., 1994, 59, 3512-3513.

8 (a) A. Doléans-Jordheim, J.-B. Veron, O. Fendrich, E. Bergeron, A. Montagut-Romans, Y.-S. Wong, B. Furdui, J. Freney, C. Dumontet and A. Boumendjel, ChemMedChem, 2013, 8, 652-657; (b) K. Kobayashi, T. Kitamura, K. Yoneda, O. Morikawa and H. Konishi, Chem. Lett., 2000, 798-799; (c) N. S. Mani, J.-H. Chen, J. P. Edwards, M. Wu, P. Chen and R. I. Higuchi, Tetrahedron Lett., 2008, 49, 1903-1905; (d) R. Manikandan and M. Jeganmohan, Org. Lett., 2014, 16, 3568-3571; (e) K. Inamoto, T. Saito, K. Hiroya and T. Doi, J. Org. Chem., 2010, 75, 3900-3903; (f) R. Berrino, S. Cacchi, G. Fabrizi and A. Goggiamani, J. Org. Chem., 2012, 77, 2537-2542.

9 (a) A. Kubo, S. Nakahara and Y. Tanaka, Heterocycles, 1996, 43, 2113-2123; (b) Y. Kitahara, S. Nakahara, M. Shimizu, T. Yonezawa and A. Kubo, Heterocycles, 1993, 36, 19091924; (c) M. Nakakoshi, S. Saito, Y. Shimokawa, M. Tsubuki, H. Suzuki, Y. Yokoyama, A. Ishigami and H. Nishioka, Heterocycles, 2012, 85, 1933-1940; (d) Y. Fujiwara, C. Jia, T. Kitamura and D. Piao, J. Org. Chem., 2000, 65, 7516-7522; (e) N. Wlodarczyk, C. Simenel, M. Delepierre, J.-C. Barale and Y. L. Janin, Synthesis, 2011, 934-942; (f) Array Biopharma Inc., Patent WO, 2008/121687, 2008; $(g)$ C. Bonnefous, J. E. Payne, J. Roppe, H. Zhuang, X. Chen, K. T. Symons, P. M. Nguyen, M. Sablad, N. Rozenkrants, Y. Zhang, L. Wang, D. Severance, J. P. Walsh, N. Yazdani, A. K. Shiau, S. A. Noble, P. Rix, T. S. Rao, C. A. Hassig and N. D. Smith, J. Med. Chem., 2009, 52, 3047-3062; (h) R. Friesen, R. N. Young, Y. Girard, M. Blouin and D. Dube, Patent US, 5410054, 1995; (i) Y. Shibata, T. Shibuya, K. Tanaka and K. Noguchi, Angew. Chem., Int. Ed., 2011, 50, 3963-3967.

10 (a) Z. Fu, K. Jiang, T. Zhu, J. Torres and Y. R. Chi, Angew. Chem., Int. Ed., 2014, 53, 6506-6510; (b) D. R. Boyd, 
N. D. Sharma, L. V. Modyanova, J. G. Carroll, J. F. Malone, C. C. R. Allen, J. T. G. Hamilton, D. T. Gibson, R. E. Parales and H. Dalton, Can. J. Chem., 2002, 80, 589-600; (c) C. Chopard, R. Azerad and T. Prangé, J. Mol. Catal. B, 2008, 50, 53-60; (d) O. Rudolf, M. Rouchal, A. Lycka and A. Klasek, Helv. Chim. Acta, 2013, 96, 1905-1917.

11 (a) D. Arlt, M. Bieniek and R. Karch, Patent US, 0113795, 2010; (b) K. L. Grela, A. A. Michrowska and M. Bieniek, Patent US, 0319199, 2008; (c) R. L. Pederson, J. K. Woertink, C. M. Haar, D. E. Gindelberger and Y. Schrodi, Patent US, 6620955, 2003; (d) R. Bujok, M. Bieniek, M. Masnyk, A. Michrowska, A. Sarosiek, H. Steüpowska, D. Arlt and K. Grela, J. Org. Chem., 2004, 69, 6894-6896; (e) S. R. Waldman, A. P. Monte, A. Bracey and D. E. Nichols, Tetrahedron Lett., 1996, 37, 7889-7892.

12 (a) M. G. Banwell, D. W. Lupton, X. Ma, J. Renner and M. O. Sydnes, Org. Lett., 2004, 6, 2741-2744; (b) E. RiveraBecerril, N. Pérez-Fernández, P. Joseph-Nathan and M. S. Morales-Ríos, Heterocycles, 2006, 68, 1459-1466; (c) G. Battistuzzi, R. Bernini, S. Cacchi, I. De Salve and G. Fabrizi, Adv. Synth. Catal., 2007, 349, 297-302; (d) K. Inamoto, J. Kawasaki, K. Hiroya, Y. Kondo and T. Doi, Chem. Commun., 2012, 48, 4332-4334.

13 (a) L. A. Hay, T. M. Koenig, F. O. Ginah, J. D. Copp and D. Mitchell, J. Org. Chem., 1998, 63, 5050-5058; (b) L. A. Hay and D. Mitchell, Tetrahedron Lett., 1997, 38, 6533-6536.

14 K. Rikimaru, T. Wakabayashi, H. Abe, T. Tawaraishi, H. Imoto, J. Yonemori, H. Hirose, K. Murase, T. Matsuo, M. Matsumoto, C. Nomura, H. Tsuge, N. Arimura, K. Kawakami, J. Sakamoto, M. Funami, C. D. Mol, G. P. Snell, K. A. Bragstad, B.-C. Sang, D. R. Dougan, T. Tanaka, N. Katayama, Y. Horiguchi and Y. Momose, Bioorg. Med. Chem., 2012, 20, 3332-3358.

15 (a) V. Calò, A. Nacci, A. Monopoli, L. López and A. di Cosmo, Tetrahedron, 2001, 57, 6071-6077; (b) G. H. Baek, S. J. Cho, Y. S. Jung, C.-M. Seong, C.-W. Lee and N.-S. Park, Bull. Korean Chem. Soc., 1999, 20, 232-236.

16 L. Wu, S. Qiu and G. Liu, Org. Lett., 2009, 11, 2707-2710.

17 (a) M. W. Bundesmann, S. B. Coffey and S. W. Wright, Tetrahedron Lett., 2010, 51, 3879-3882; (b) A. Khalafi-Nezhad, A. Parhami, M. N. S. Rad and A. Zarea, Tetrahedron Lett., 2005, 46, 6879-6882.

18 M. Wasa and J.-Q. Yu, J. Am. Chem. Soc., 2008, 130, 1405814059.

19 (a) R. Bernini, S. Cacchi, G. Fabrizi and A. Sferrazza, Heterocycles, 2006, 69, 99-105; (b) H. Benakki, E. Colacino, C. Andre, F. Guenoun, J. Martinez and F. Lamaty, Tetrahedron, 2008, 64, 5949-5955; (c) M. H. Al-Huniti, M. M. El-Abadelah, J. A. Zahra, S. S. Sabri and A. Ingendoh, Molecules, 2007, 12, 1558-1568.

20 (a) T. Harayama, K. Nakatsuka, H. Nishioka, K. Murakami, Y. Ohmori, Y. Takeuchi, H. Ishii and K. Kenmotsu, Heterocycles, 1994, 38, 2729-2738; (b) M. C. Wani and M. E. Wall, J. Org. Chem., 1969, 34, 1364-1367; (c) D. A. Horton, G. T. Bourne, J. Coughlan, S. M. Kaiser, C. M. Jacobs,
A. Jones, A. Rühmann, J. Y. Turner and and M. L. Smythe, Org. Biomol. Chem., 2008, 6, 1386-1395; (d) L. P. Miranda, W. D. F. Meutermans, M. L. Smythe and P. F. Alewood, J. Org. Chem., 2000, 65, 5460-5468; (e) A. Robinson and B. Van Lierop, Patent $W O, 146973,2011 ;(f)$ T. B. Lowinger, T. Murata, M. Umeda, S. Sakakibara, T. Yoshino, H. Sato, T. Masuda, Y. Koriyama, M. Shimada, T. Shintani, H. Kadono, K. B. Ziegelbauer, K. Fuchikami and H. Komura, Patent WO, 024679, 2002; $(g)$ B. Shen, D. Loeffler, K.-P. Zeller, M. Uebele, G. Reischl and H.-J. Machulla, J. Fluor. Chem., 2007, 128, 1461-1468.

21 (a) J. Wu and C. Yue, Synth. Commun., 2006, 36, 2939-2947; (b) H. Lebel, C. Ladjel and L. Bréthous, J. Am. Chem. Soc., 2007, 129, 13321-13326; (c) A. Bouziane, M. Hélou, B. Carboni, F. Carreaux, B. Demerseman, C. Bruneau and J. L. Renaud, Chem. - Eur. J., 2008, 18, 5630-5637.

22 B. E. Maryanoff and A. B. Reitz, Chem. Rev., 1989, 89, 863927.

23 J. C. Pastre and C. R. D. Correia, Adv. Synth. Catal., 2009, 351, 1217-1223.

24 (a) S. Gupta, B. Ganguly and S. Das, RSC Adv., 2014, 4, 41148-41151; (b) J. G. Taylor and C. R. D. Correia, J. Org. Chem., 2011, 76, 857-869; (c) D. A. Barancelli, A. G. Salles Jr., J. G. Taylor and C. R. D. Correia, Org. Lett., 2012, 14, 6036-6039; (d) J. G. Taylor, A. V. Moro and C. R. D. Correia, Eur. J. Org Chem., 2011, 1403-1428; (e) J. G. Taylor, R. da Silva Ribeiro and C. R. D. Correia, Tetrahedron Lett., 2001, 52, 3861-3864.

25 K. H. Kim, S. Lee, S. H. Kim, C. H. Lim and J. N. Kim, Tetrahedron Lett., 2012, 53, 5088-5093.

26 (a) H. R. Bernini, S. Cacchi, I. De Salve and G. Fabrizi, Synlett, 2006, 2947-2952; (b) C. Costa Oliveira and C. R. D. Correia, Substrate-Directed Heck-Matsuda Arylations: From Curiosity to a Valuable Synthetic Tool in Strategies and Tactics in Organic Synthesis, ed. M. Harmata, Elsevier, Amsterdam, 2014, vol. 10, pp. 1-32; (c) A. H. Hoveyda, D. A. Evans and G. C. Fu, Chem. Rev., 1993, 93, 1307-1370.

27 J.-F. Paquin, C. R. J. Stephenson, C. Defieber and E. M. Carreira, Org. Lett., 2005, 7, 3821-3824.

28 (a) F. D. Bellamy and K. Ou, Tetrahedron Lett., 1984, 25, 839-842; (b) G. Rai, J. M. Jeong, Y. S. Lee, H. W. Kim, D. S. Lee, J. K. Chung and M. C. Lee, Tetrahedron Lett., 2005, 46, 3987-3990; (c) A. B. Gamble, J. Garner, C. P. Gordon, S. M. J. O'Conner and P. A. Keller, Synth. Commun., 2007, 37, 2777-2786.

29 (a) S. Chandrappa, K. Vinaya, T. Ramakrishnappa and K. S. Rangappa, Synlett, 2010, 3019-3022; (b) V. Guay and P. Brassard, J. Heterocycl. Chem., 1987, 24, 1649-1652; (c) D. C. Owsley and J. J. Bloomfield, Synthesis, 1977, 118120; (d) R. A. Bunce, B. Nammalwar and L. M. Slaughter, J. Heterocycl. Chem., 2009, 46, 854-860; (e) C. Ramesh, Synlett, 2011, 587-588; $(f)$ R. Di Santo, R. Costi, M. Forte and C. Galeffi, ARKIVOC, 2004, v, 181-195.

30 (a) R. I. Higuchi, A. W. Thompson, J.-H. Chen, T. R. Caferro, M. L. Cummings, C. P. Deckhut, M. E. Adams, C. M. Tegley, J. P. Edwards, F. J. López, 
E. A. Kallel, D. S. Karanewsky, W. T. Schrader, K. B. Marschke and L. Zhi, Bioorg. Med. Chem. Lett., 2007, 17, 5442-5446; (b) G. Ertl, H. Knözinger, F. Schüth and J. Weitkamp, Handbook of Heterogeneous Catalysis, WileyVCH, Weinheim, 2nd edn, 2008, vol. 1, p. 3303; (c) D. Caine and T. L. Smith Jr., J. Am. Chem. Soc., 1980, 102, 7568-7570.

31 (a) W. Stadlbauer, W. De Cecco, G. Hojas, J. Kremsner, M. Pazicky, A. Terec-Suciu, P. Traar and G. Uray, Poster A008, Sixth International Electronic Conference on Synthetic Organic Chemistry (ECSOC-6), http://www.mdpi.net/ecsoc-6, September 1-30, 2002; (b) Z.-X. Guo, A. N. Cammidge, A. McKiilop and D. C. Horwell, Tetrahedron Lett., 1999, 40, 6999-7002.

32 (a) A. Guiotto, A. Chilin and G. Pastorini, J. Heterocycl. Chem., 1989, 26, 917-922; (b) P. Rodighiero, G. Bandoli, A. Chilin, P. Manzini and A. Guiotto, J. Heterocycl. Chem., 1993, 30, 715-722; (c) Y. Kyotani, T. Ohgiya, T. Toma, Y. Kurihara, T. Kitamura, T. Yamaguchi, K. Onogi, S. Sato, H. Shigyo, T. Ohta, M. Kawada and Y. Uchida, Patent US, 5576324, 1996; (d) Y. Oshiro, T. Tanaka, T. Nishi, K. Kuwahara, S. Fujisawa, K. Takasu and Y. Wada, Patent US, 5786367, 1998; (e) T. B. Hurley, K. Lee, S. Peukert and S. Wattanasin, Patent US, 2009/0325948, 2009 .
33 (a) J. M. Hastings, M. K. Hadden and B. S. J. Blagg, J. Org. Chem., 2008, 73, 369-373; (b) N. A. McGrath, J. R. Binner, G. Markopoulos, M. Brichacek and J. T. Njardarson, Chem. Commun., 2011, 209-211; (c) S. J. Spessard and B. M. Stoltz, Org. Lett., 2002, 4, 1943-1946; (d) J. G. Kodet, J. J. Topczewski, K. D. Gardner and D. F. Wiemer, Tetrahedron, 2013, 69, 9212-9218.

34 Z.-W. Zhou, W.-C. Li, Y. Hu, B. Wang, G. Ren and L.-H. Feng, Res. Chem. Intermed., 2013, 39, 3049-3054.

35 (a) S. M. Podhajsky and M. S. Sigman, Organometallics, 2007, 26, 5680-5686; (b) J. M. Wiebe, A. S. Caillé, L. Trimble and C. K. Lau, Tetrahedron, 1996, 52, 1170511724; (c) M. M. Toteva and J. P. Richard, Adv. Phys. Org. Chem., 2011, 45, 39-91; (d) M. S. Singh, A. Nagaraju, N. Ananda and S. Chowdhurya, RSC Adv., 2014, 4, 5592455959.

36 (a) A. Mouaddib, B. Joseph, A. Hasnaoui and J.-Y. Merour, Synthesis, 2000, 549-556; (b) Z.-Y. Yang, Y. Xia, P. Xia, A. Brossi, L. M. Cosentino and K.-H. Lee, Bioorg. Med. Chem. Lett., 2000, 10, 1003-1005.

37 H. Wagner, S. Bladt and V. Rickl, Drug Analysis: A Thin Layer Chromatography Atlas, Springer, Heidelberg, 2nd edn, 2009, p. 360.

38 Z. Liu, S. Yang, C. Zhu and J. Gao, Gaodeng Xuexiao Huaxue Xuebao, 1988, 9, 203-205, (Chem. Abstr., 1988, 610838). 